\title{
THE EVOLUTION OF TOP INCOME AND WEALTH SHARES IN PORTUGAL SINCE 1936*
}

JORDI GUILERA

Universitat de Barcelona ${ }^{\mathrm{a}}$

\begin{abstract}
This paper presents new statistical evidence on the long-term evolution of economic inequality in Portugal. Portuguese tax sources have been employed to estimate top income and wealth shares (TIS and TWS) from 1936 onwards. The new series shows that the Second World War had a negative and non-permanent effect on the evolution of TIS, but not on TWS, which increased until the mid 1950s. From the mid 1950s to the early 1980s, there was a sharp decline in TIS and TWS. Finally, during the 1990s, TIS increased again. The reasons behind the Portuguese distributive pattern seem to be more economic than political.
\end{abstract}

Keywords: top incomes, Portugal, economic inequality

JEL Code: D31, O15, H24

* Received 24 July 2008. Accepted 26 November 2009. I thank Alfonso Herranz for his continuous support and stimulus. I also thank all the participants of the XXVII APHES Congress in Lisbon, the Barcelona Workshop on Economic Inequality and the Origins of the Welfare State in Spain and Portugal and the Third Summer School «Unifying the European experience ... » hosted in Paris for their insightful comments, especially Natalia Mora-Sitja and Jaime Reis. I am especially indebted to the three anonymous referees who made important contributions to the improvement of the first version of the paper. This research has also benefited from a research period at the Instituto da Ciências Sociais under the supervision of Pedro Lains. Finally, financial support from the research Project ECO2009-13331-C02-02 financed by Innovation and Science Ministry of Spain, the Economic History Department (UB), the $\mathrm{R}+\mathrm{D}+\mathrm{I}$ Reference Network in Economics and Public Policies of the Generalitat de Catalunya and the ESF (GlobalEuroNet) is gratefully acknowledged.

a Facultat de Ciències Econòmiques i Empresarials. Departament d'Història i Institucions Econòmiques. Universitat de Barcelona. Diagonal, 690, 08034 Barcelona, Spain. jguilera@ub.edu 


\section{RESUMEN}

El objetivo de este artículo es presentar nueva información estadística sobre la evolución de las desigualdades económicas en Portugal a largo plazo. La explotación de las fuentes fiscales portuguesas ha permitido la estimación de las top income and wealth shares (TIS y TWS) desde 1936. Estas nuevas series revelan que la Segunda Guerra Mundial tuvo un impacto negativo no permanente sobre las TIS, pero no sobre las TWS. Desde mediados de los cincuenta hasta principios de los ochenta, TIS y TWS cayeron con intensidad. Finalmente, durante los años noventa las TIS volvieron a aumentar. Las razones que hay detrás de la pauta distributiva portuguesa parecen ser más de índole económica que política.

Palabras clave: top incomes, Portugal, desigualdades económicas

\section{INTRODUCTION}

The last decade of the $20^{\text {th }}$ century was characterized by the reincorporation of the study of inequality to the core of economic analysis. Academic interest in distributive issues has since had two different objectives: on the one hand, the analysis of economic inequality as an endogenous variable (trying to explain distributive patterns) and, on the other hand, its study as an exogenous variable (analysing its impact on other variables such as economic growth). This paper adopts the first perspective and tries to describe and explain the evolution of inequality in Portugal over the $20^{\text {th }}$ century.

There are not many analyses of long-term Portuguese inequality. In a recent paper, Lains et al. (2008) estimated and analysed the evolution of Portuguese wage dispersion between 1944 and 1974. This paper, however, provides an estimation of top incomes and wealth shares from 1936 onwards as the main empirical basis of the analysis.

Historical estimation of top income and wealth shares (TIS and TWS) from fiscal sources is a frequent strategy to measure long-term inequality, given the scarcity of other sources of information that could provide better and more comprehensive indicators, such as household budget surveys (see Atkinson and Piketty 2007). Although TIS are a partial measure of inequality, Leigh (2007) demonstrated that they may constitute a good proxy for global income inequality for the second half of the $20^{\text {th }}$ century. The new indicators of long-term Portuguese economic inequality presented here may contribute to increase the number of countries for which information on TIS and TWS is available. 
The Portuguese TIS presented in this paper show a decrease in inequality during the Second World War, which was then compensated for in the early 1950s. In contrast, TWS remained unaffected by the conflict and grew continuously until the mid 1950s. From the mid 1950s till the early 1980s, both TIS and TWS declined sharply. Finally, during the 1990s, TIS increased again.

This is not the only estimation of Portuguese TIS. Alvaredo $(2008,2009)$ provided an alternative series, which has some differences from ours. Appendix 2 of this paper analyses these differences and shows that they are a result of a more critical study and discussion of the sources in our case, which is accompanied by greater transparency in the treatment of data and also a more accurate and balanced interpretation of the results.

The study of the Portuguese case has an intrinsic value, because it allows an analysis of the distributive impact of the two features which, according to economic theory, are essential to an understanding of the evolution of inequality: political regimes (dictatorship vs. democracy) and economic growth. In this regard, in 1926, a military coup put an end to the Republican period in Portugal and established a dictatorship that lasted till 1974. This was characterized by intense political repression and a significant lack of public liberties. This long dictatorship also prohibited labour unions and any kind of workers' movement in order to keep wages down, a situation which should have increased income inequality. In spite of this, from the mid 1950s onwards, inequality, measured through both TIS and TWS, began to diminish. After the Revoluçao dos Cravos of 25 April 1974, which marked the end of the dictatorship and opened the democratic era, TIS and TWS continued falling, but at the same pace as during the pre-democratic era. Finally, the last years of the $20^{\text {th }}$ century were characterized by an intense increase in TIS. At first sight it would seem that, contrary to what could be expected, political variables were not decisive in determining distributive patterns in Portugal throughout the $20^{\text {th }}$ century.

The other main characteristic feature of recent Portuguese history was the country's rapid economic growth during the golden age of capitalism. Portugal, following the south European pattern, was catching up quickly with the core European countries during most of the $20^{\text {th }}$ century (Lains 2003a). These new TIS and TWS series, jointly with the estimation of global wage inequality between 1944 and 1974 by Lains et al. (2008), point to the fact that structural change was the main force driving the evolution of income inequality during the transition from an agrarian economy towards an industrialized and service-oriented one.

The remainder of this paper is structured as follows: section 2 presents the data and methodology used; section 3 shows the main results; section 4 tries to account for the causes behind the inequality trends and section 5 concludes. 


\section{DATA AND METHODOLOGY}

The methodology used to derive TIS and TWS is based on the pioneering paper by Piketty (2001) and involves estimating the TIS and TWS of the richest fractiles of the population. Information on individual incomes and wealth comes from tax return statistics, structured in different income and wealth brackets. To obtain the different TIS and TWS, the number of tax units and their incomes or wealth is divided by the total reference population and the total reference income or wealth, respectively. The estimation of income and wealth thresholds and the income and wealth belonging to each fractile is calculated by assuming that incomes and wealth are distributed according to a Pareto function.

\subsection{Top Income Shares}

The main basis for the estimation of TIS is Portuguese income tax, which underwent significant transformations after the first attempt to introduce it, in the context of the failed fiscal reform in 1922. The ambition and complexity of this reform, the prevailing administrative weakness, government instability and tax evasion are some of the factors that may explain the complete failure to implement the tax system in that year. In 1929, a commission headed by Antonio de Oliveira Salazar designed a new fiscal reform aimed at producing a simpler system, one that was more likely to be applied. The main concern of the reformers was to increase public revenues in order to be able to balance the government budget, which had been out of control since the First World War (Leitao 2001) ${ }^{1}$.

The new fiscal system did not imply a complete change with respect to the previous one, and was characterized by the existence of several taxes for specific types of income. These different taxes were applicable to the «normal» or presumed returns of taxpayers, and not to the actual figures as in modern fiscal systems. The sum of all the returns assessed by the specific taxes was then taxed again by the imposto complementar (complementary tax) with progressive rates. More specifically, the returns taxed by the imposto complementar were the sum of the assessed returns in the contribuiçao predial (land tax), imposto sobre a industria agrícola ${ }^{2}$ (agricultural industry tax), contribuiçao industrial (industrial tax), imposto profissional (professional tax) and imposto sobre a aplicaçao de capitais (capital tax). The imposto complementar had two sections: section A for individuals and

\footnotetext{
1 Although monetary stability was first achieved in 1924, during the Republican period, the years immediately after the 1926 military coup saw the financial situation get substantially worse (Valerio 1994)

2 This tax was created in 1963 but was only collected in 1964, 1975, 1981, 1982, 1984, 1987 and 1988.
} 
section B for entities. The replacement of the imposto pessoal (the failed personal tax system established in the 1922 reform) by the imposto complementar was a step backwards in terms of modernizing the design of the Portuguese fiscal system, but it had two positive features: it introduced a soft personalization and, most importantly, it was fully implemented ${ }^{3}$.

This system remained effective until the 1958-1965 fiscal reform, which was intended to introduce real income assessment and to leave behind the «normal» or presumed income tax system. Nevertheless, it maintained the prevailing fiscal structure, that is to say, separate taxes for different kinds of incomes and a superposed tax over them all: the imposto complementar. This reform was drawn up by a commission headed by Teixeira Ribeiro, who some years later denounced the move away from the principles established in the reform, such as the return determination system, which, in some cases, ended up being characterized again by the "normal» or presumed income assessment (Ribeiro 1968).

Later, the new constitution approved in 1976 set out the principles that should characterize the Portuguese fiscal system under the new democracy. However, although these principles contradicted the existing tax structure, the necessary fiscal reform was not implemented until 1988. This reform was guided by three principles: equity, efficiency and simplicity. The previous system was completely abandoned. The taxation of personal incomes became entirely covered by one single tax: the imposto sobre o rendimento. This tax has two sections, the IRS (imposto sobre o rendimento das pessoas singulares) for individuals, which has been used for our estimations, and the IRC (imposto sobre o rendimento das pessoas colectivas) for entities. The IRS is direct, personal and based on real returns assessment. This latter reform allowed Portugal to join the group of countries with a modern fiscal system.

As regards tax rates, these have always been progressive, although they have changed significantly since the first personal income tax was established. The tax rate structure evolved in two different directions. On the one hand, the number of marginal rates decreased from almost 200 during the 1930 s to between four and five during the 1990s. On the other hand, the top marginal tax rate increased rapidly after the mid 1940s. It was 4.97 per cent until 1945, rose to 30 per cent between 1946 and 1963, to 45 per cent between 1964 and 1975 and to 80 per cent between 1976 and 1981, after the Revoluçao dos cravos, during the period in which the extreme left ruled the country.

\footnotetext{
3 Between 1940 and 1950, there was another income tax, the imposto suplementar (supplementary tax), which had two sections: section A was levied on some of the incomes assessed by the imposto profissional and section B on incomes coming from public positions or companies. Given that income assessed by the imposto profissional was already included in the imposto complementar, section A of imposto suplementar has not been considered here. It would, however, have been useful to include section B in the estimation, but it was not possible due to the characteristics of the sources. In spite of this, the imposto sumplementar had a minor quantitative importance and its exclusion is not likely to have biased our estimations.
} 
TABLE 1

INCOME TAX COVERAGE IN PORTUGAL (1936-2000)

\begin{tabular}{|c|c|c|c|c|c|c|c|c|c|c|}
\hline 1936 & 1937 & 1938 & 1939 & $\mathbf{1 9 4 0}$ & $\mathbf{1 9 4 1}$ & $\mathbf{1 9 4 2}$ & $\mathbf{1 9 4 3}$ & $\mathbf{1 9 4 4}$ & $\mathbf{1 9 4 5}$ & $\mathbf{1 9 4 6}$ \\
$1.4 \%$ & $1.5 \%$ & $1.5 \%$ & $1.6 \%$ & $1.7 \%$ & $1.8 \%$ & $1.9 \%$ & $2.1 \%$ & $2.2 \%$ & $2.9 \%$ & $0.3 \%$ \\
\hline $\mathbf{1 9 4 7}$ & $\mathbf{1 9 4 8}$ & $\mathbf{1 9 4 9}$ & $\mathbf{1 9 5 0}$ & $\mathbf{1 9 5 1}$ & $\mathbf{1 9 5 2}$ & $\mathbf{1 9 5 3}$ & $\mathbf{1 9 5 4}$ & $\mathbf{1 9 5 5}$ & $\mathbf{1 9 5 6}$ & $\mathbf{1 9 5 7}$ \\
$0.4 \%$ & $0.5 \%$ & $0.5 \%$ & & $0.7 \%$ & $0.7 \%$ & $0.8 \%$ & $0.8 \%$ & $0.8 \%$ & $1.0 \%$ & $1.0 \%$ \\
\hline $\mathbf{1 9 5 8}$ & $\mathbf{1 9 5 9}$ & $\mathbf{1 9 6 0}$ & $\mathbf{1 9 6 1}$ & $\mathbf{1 9 6 2}$ & $\mathbf{1 9 6 3}$ & $\mathbf{1 9 6 4}$ & $\mathbf{1 9 6 5}$ & $\mathbf{1 9 6 6}$ & $\mathbf{1 9 6 7}$ & $\mathbf{1 9 6 8}$ \\
$1.1 \%$ & $1.0 \%$ & $0.9 \%$ & $0.9 \%$ & $1.0 \%$ & $1.2 \%$ & $0.8 \%$ & $1.3 \%$ & $1.3 \%$ & $1.5 \%$ & $1.7 \%$ \\
\hline $\mathbf{1 9 6 9}$ & $\mathbf{1 9 7 0}$ & $\mathbf{1 9 7 1}$ & $\mathbf{1 9 7 2}$ & $\mathbf{1 9 7 3}$ & $\mathbf{1 9 7 4}$ & $\mathbf{1 9 7 5}$ & $\mathbf{1 9 7 6}$ & $\mathbf{1 9 7 7}$ & $\mathbf{1 9 7 8}$ & $\mathbf{1 9 7 9}$ \\
$1.9 \%$ & $2.2 \%$ & $2.5 \%$ & $3.0 \%$ & $3.5 \%$ & $4.1 \%$ & $3.5 \%$ & $18.2 \%$ & $14.7 \%$ & & $17.9 \%$ \\
\hline $\mathbf{1 9 8 0}$ & $\mathbf{1 9 8 1}$ & $\mathbf{1 9 8 2}$ & $\mathbf{1 9 8 3}$ & $\mathbf{1 9 8 4}$ & $\mathbf{1 9 8 5}$ & $\mathbf{1 9 8 6}$ & $\mathbf{1 9 8 7}$ & $\mathbf{1 9 8 8}$ & $\mathbf{1 9 8 9}$ & $\mathbf{1 9 9 0}$ \\
$21.0 \%$ & $27.6 \%$ & & & & & & & & $46.6 \%$ & $57.0 \%$ \\
\hline $\mathbf{1 9 9 1}$ & $\mathbf{1 9 9 2}$ & $\mathbf{1 9 9 3}$ & $\mathbf{1 9 9 4}$ & $\mathbf{1 9 9 5}$ & $\mathbf{1 9 9 6}$ & $\mathbf{1 9 9 7}$ & $\mathbf{1 9 9 8}$ & $\mathbf{1 9 9 9}$ & $\mathbf{2 0 0 0}$ & \\
$57.0 \%$ & $59.0 \%$ & $57.0 \%$ & $59.4 \%$ & $58.1 \%$ & $60.4 \%$ & $62.8 \%$ & $63.7 \%$ & $64.9 \%$ & $68.3 \%$ & \\
\hline
\end{tabular}

Source: Estatística das contribuçoes e impostos and population censuses.

Finally, in 1989, it was fixed at 40 per cent. The effects of the second process (the increase in the top marginal tax rate) have been much more intense than those of the first one (the decrease in the number of marginal tax rates) and, as a consequence, Portuguese personal tax has become increasingly progressive since its introduction.

The establishment of an income tax was a slow and progressive phenomenon in most countries over the $20^{\text {th }}$ century. At first, it usually covered a small fraction of the total population, which increased subsequently. In this regard, the Portuguese experience is not an exception. As shown in Table 1, the population covered by the income tax increased from 1936 to 1945 , then fell substantially in 1946 (from 2.91 to 0.39 per cent) and, from then on, increased continuously, reaching 68.3 per cent in 2000. This coverage level has allowed the yearly estimation of the top 0.5 per cent income share for the whole period under study. In contrast, there is no information on the top 1 per cent share between 1946 and 1956, and the top 5 and 10 per cent can only be calculated from 1976 onwards, when the coverage increased significantly. In addition, in the Portuguese case, the problem of the low coverage of the income tax is made worse by the exemption for public servants and military personnel from the tax. This exemption, however, is probably not a serious problem for the estimation of the upper TIS presented in this paper, because, as may be seen in Figure 1, those groups' incomes were not high enough to be included within the top 1 per cent income group. The statistical information published by the Portuguese Ministry of Finance on the income tax returns also varied across time. In order to estimate TIS, the best possible 
FIGURE 1

YEARLY INCOMES OF DIFFERENT PUBLIC EMPLOYEES AND MILITARY PERSONNEL AND AVERAGE INCOMES OF THE RICHEST 1 PER CENT GROUP IN PORTUGAL

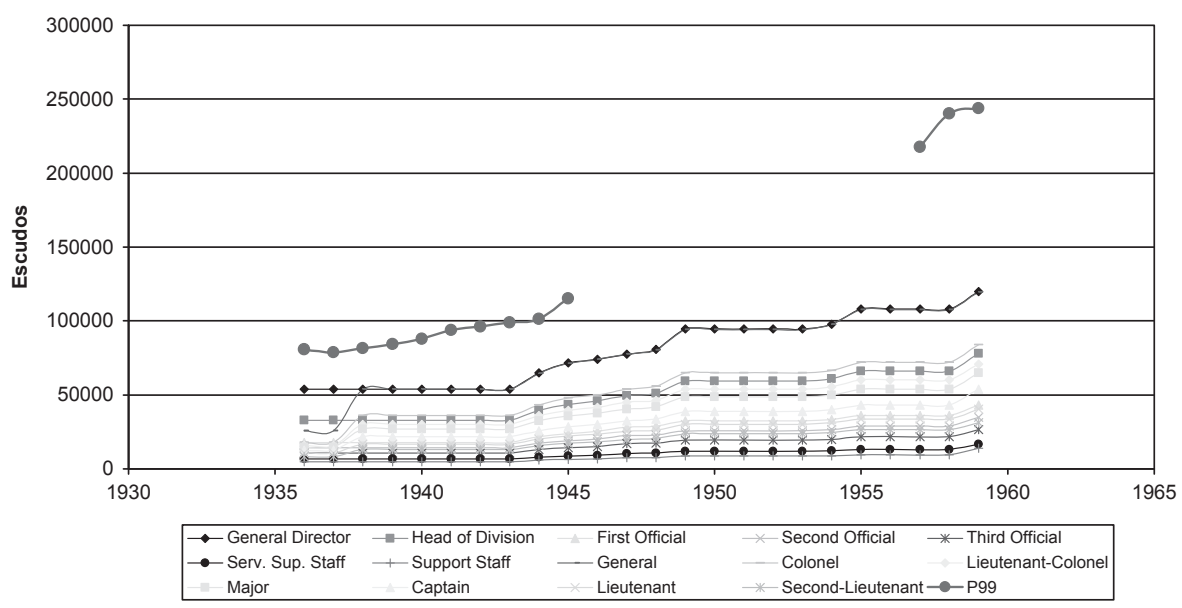

Source: Oliveira Marques (1991) and Batista et al. (1997).

statistical information would be the total returns assessed for each tax unit, distributed among different income brackets. Unfortunately, this information is not available for the whole period studied and a number of adjustments have been necessary in order to obtain a homogeneous series.

From 1936 to 1945, there is information on the number of tax units, classified into different brackets according to the tax paid. In order to obtain TIS, it has been necessary, first, to classify the information according to the income assessed by each tax unit, rather than to the taxes paid. This was achieved by dividing each bracket threshold by its corresponding tax rate. The second step involves estimating the total amount of income assessed in each bracket. This was done by assuming that the returns were Pareto distributed ${ }^{4}$.

From 1946 to 1963, the statistics published by the Ministry of Finance regarding the imposto complementar give information on the total incomes of all tax units, classified in different income brackets. In addition, for each bracket, there is information on the number of tax units. This is the information needed for the construction of the series, so no adjustment is necessary.

From 1964 to 1981, the statistics published have the same structure, but the concept of income is now taxable income, that is, total income less deductions. There were six kinds of deductions, regulated by the articles 3 ,

\footnotetext{
4 The standard Pareto interpolation method was already used by Kuznets (1953); see Feenberg and Poterba (1993).
} 
$28,29,30,84$ and 91 of the complementary tax code. Sixty-eight per cent of deductions were due to article 29 and associated with family circumstances (a personal deduction, a deduction per partner and per number of children). A further 27 per cent of deductions were due to article 28 and were associated with different circumstances, such as different specific taxes paid, social contributions paid by workers, interests and debt obligations, pensions paid by taxpayers and half of the remunerations received by wage-earners. The remaining articles were of minor importance and only accounted for 5 per cent of the total deductions. There is, however, no clear way of knowing how the deductions were distributed among tax units. Were they regressive or progressive? The description of deductions in the tax code is too generalist and does not allow deductions to be added to taxable income. Here, it has been assumed that they were distributed in the same way as before 1963, when there is information on both total income and taxable income distributed among different brackets ${ }^{5}$. It must be stressed that deductions were quantitatively very important (about 60 per cent of taxable income).

Between 1982 and 1988, statistical information is too aggregated, and does not distinguish between different income brackets. This prevents the estimation of TIS for most of the 1980s. Finally, from 1989 onwards, the official statistics give the same information as between 1946 and 1963. Again, no adjustment is necessary.

The number of income brackets in which tax statistics are classified also varied across time. Until 1945 there were nine income brackets, while between 1945 and 1963, this number rose to thirty-one. Between 1964 and 1976, the number of brackets decreased again to sixteen, falling further to twelve in the period up to 1979 and to eleven up to 1981. During the last period, from 1989 onwards, the number of income brackets was fixed at twenty. In general, although more brackets allow better estimations (less dependent on Pareto assumptions), the number of income brackets over this period is sufficient to guarantee the robustness of the estimations.

Once a homogeneous series for the total income of taxpayers, distributed in different brackets according to their income, has been obtained, the income shares of the top fractiles (P90, P95, P99, P99.5, P99.9, P99.95 and P99.99, equivalent to the top 10, 5 and 1 per cent income shares, etc.) can be estimated. To this end, the first step involves defining the number of tax units that formed the top fractiles. The unit of taxation of Portuguese income tax is a married couple or a single individual. In order to estimate the total reference population, the number of married women has been subtracted from the total population aged 20 years or above. This information has been taken from the Portuguese population censuses, which were published decennially during the period under study. The values between census years have been obtained through linear interpolation.

\footnotetext{
${ }^{5}$ Appendix 1 gives a detailed explanation of the method used to allocate deductions.
} 
The following step consists of estimating the income threshold of each fractile, that is, the income of the poorest member of each fractile, and then estimating the amount of income above each fractile's income threshold ${ }^{6}$. Finally, this amount must be divided by the total reference income.

The total reference income should have been obtained from the national accounts, by subtracting from the personal sector income (PSI) those concepts on which income tax was not levied ${ }^{7}$. However, in the case of Portugal, the information needed to make this adjustment is not available for the whole period under study and, therefore, it has been necessary to take the PSI as the total reference income. PSI figures for 1953-1994 are from Pinheiro (1997) and, from 1995 onwards, from the national accounts published online by the INE (National Statistics Institute). Before 1953, PSI figures are not available, and it has been assumed that, between 1936 and 1952, the average PSI/GDP ratio was the same as in the period 1953-1962 (80.36 per cent $)^{8}$. Thus, GDP data from Batista et al. (1997) have been used to estimate yearly figures of PSI between 1936 and 1953, and a continuous series has been obtained by equalizing the values of PSI in the years in which there is a change of source (1953 and 1995), and by rescaling the series for the previous years (Figure 2).

In several years, the scarcity of data prevents us from estimating some TIS and, in these cases, the criteria established by Leigh (2007) are adopted, that is, the missing data are linearly interpolated if the number of missing years is four or fewer (p. 10) ${ }^{9}$.

The tax statistics have some discontinuities causing some breaks in the series. First, from 1945 to 1946, the characteristics of the statistical information published changed, as described above. However, the adjustments introduced in the estimation have minimized any potential distortions due to this change, and the different series estimated are fairly stable. Second, between 1963 and 1964, the fiscal system was redesigned. As a consequence, between 1963 and 1965, the data show a short but intense increase in the TIS, which may be attributable to the regulation changes in income tax. Finally, between 1982 and 1988, there is a gap in the series and the major changes in tax regulation codes that took place at the time, prevent any comparison between the level of the TIS in 1981 and 1989. Actually, TIS of 1980 turn out to be clearly understated when compared

6 To this end, the standard Pareto interpolation method has been used, see Feenberg and Poterba (1993).

7 This is the standard method followed in this kind of study, although reference income can also be obtained from tax statistics by adding those tax units not covered.

8 As can be seen in Figure 2, the PSI/GDP ratio was relatively stable from the early 1950s to the mid 1960s, but subsequently, it fluctuated severely. There is, in any case, a great degree of uncertainty surrounding the evolution of the PSI between 1936 and 1952, due to the high economic instability of that period, and the final figures may be biased as a result. However, it is not possible to correct this on the basis of the available information.

9 This was the case in (1) 1978 for all TIS; (2) 1959-1961 and 1964 for the top 1 per cent; and (3) 1946-1948 for the top 0.05 per cent. Between 1982 and 1988, data are also missing, but they have not been linearly interpolated due to the size of the gap. 
FIGURE 2

RATIO PSI/GDP

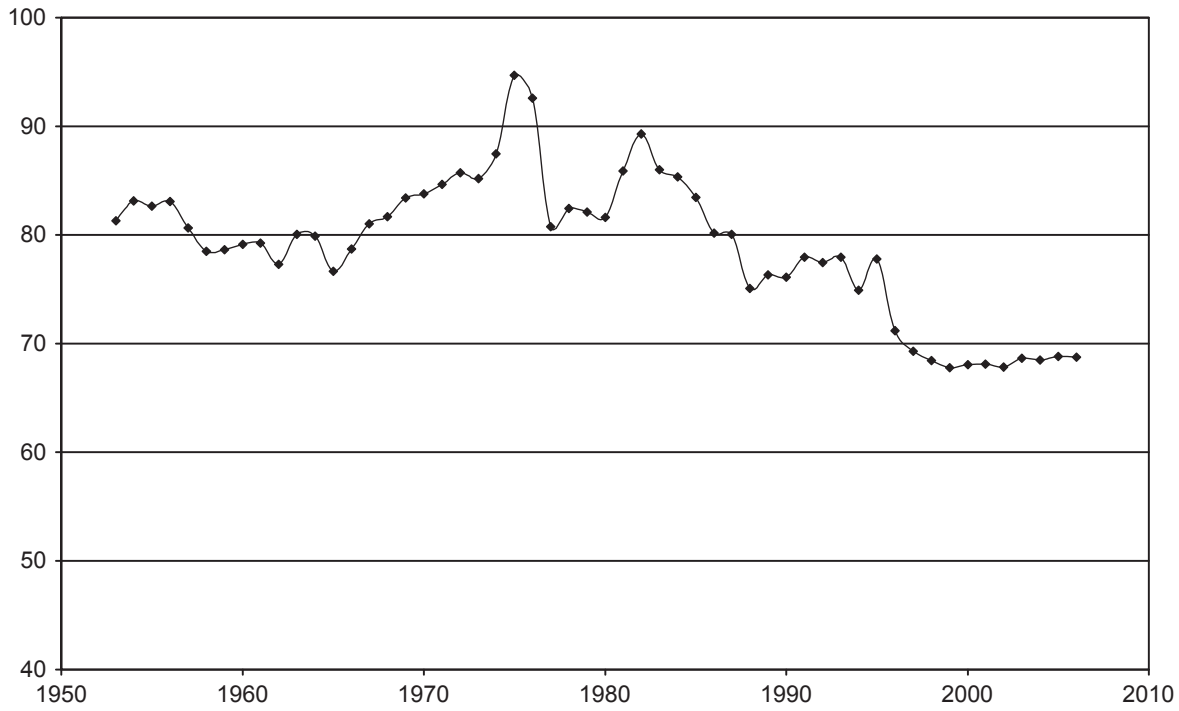

Source: Pinheiro et al. (1997), Batista et al. (1997) and INE online statistics.

with the estimate of the top 10 per cent provided by other sources such as the Household Income and Expenditure Survey (HIES) ${ }^{10}$. In sum, there are two significant discontinuities in the series (1963 and 1982-1988), which must be corrected in order to estimate long-term coherent series.

In order to have a consistent long-term view of the evolution of TIS, these discontinuities have been dealt with according to the following criteria. First, given that figures for 1965 are more reliable than those of 1963 (before the fiscal reform), the TIS levels of 1963 have been assumed to be the same as in 1965 and have been projected backwards accordingly.

Second, given that the TIS for 1980 are clearly understated, we have taken the values provided by HIES as the top 10 per cent of income shares of 1980 . The top 10 per cent income share levels of 1990 have also been modified in the same way to make them comparable with the previous years. The remaining TIS for 1980 and 1990 have been adjusted to the level of the top 10 per cent TIS. To estimate TIS after 1989, the TIS levels of 1990 have been projected backwards and forwards according to the growth rates of the different TIS. As for 1965-1980, we have kept the 1965 value, from fiscal

10 The top decile income share in 1980 is 12.5 in our series and 26.7 in HIES in 1990. 
sources, and TIS between 1965 and 1980 have been adjusted by applying the growth rate of the different TIS corrected by the ratio (fiscal TIS 1965 - HIES TIS 1980)/(fiscal TIS 1965 - fiscal TIS 1980) ${ }^{11}$.

As noted above, Appendix 2 compares our estimation of TIS with that of Alvaredo. These two estimations have three major differences: the method used to add deductions to taxable income, the total reference income and generally increased transparency in the treatment of the original data in our estimation. All these differences suggest greater reliability in the case of our series.

\subsection{Top Wealth Shares}

The methodology used to derive TWS is the same as that used to estimate TIS. The information on the individual stock of wealth is taken from the Imposto sobre sucessoes e doaçoes (estate tax). This tax was levied on the stock of wealth above a minimum threshold left by the decedents. In practice, this tax mainly assessed real estate with cadastral values (Valerio 1994). In spite of this, during the period studied, most wealth was in the form of real estate, and thus, this source would be a good proxy of the total wealth left by decedents. The Portuguese tax authorities published detailed information for estate tax returns from 1936 to 1982. However, after this year, the reported information became too aggregated to allow the estimation of TWS. The characteristics of the statistical information published until 1982 are almost constant over time, and the source reports the number of taxpayers distributed in different wealth brackets ${ }^{12}$. The total reference wealth is the total wealth declared by the decedents, and the total reference population is the number of dead people over the age of 19 years. This last piece of information was taken from the Portuguese population censuses, and figures between censuses have been obtained through linear interpolation.

11 This correction has been made to connect the TIS levels properly between 1965 and 1980 . Projecting the HIES TIS for 1980 backwards according to the growth rates obtained from fiscal sources, the TIS levels of 1965 would have been too high. Given that TIS for 1965 are relatively reliable, because this was the first year after the reform, we have preferred to maintain the TIS levels of 1965 and to correct the TIS growth rates in order to connect the series appropriately. In Guilera (2008), the series of TIS before adjusting for the breaks in the 1960s and the 1980s can be seen. A final adjustment is with regard to the biases that could have generated the normal income assessment system used until the 1960s, if it was not corrected yearly according to inflation. The comparison of the evolution of the average incomes of top fractiles with inflation rates seems to indicate that valuations were made yearly except for 1941-1943. The inflation of these years was only assumed in 1944-1945. In this sense, it is possible that the real turning point in the evolution of TIS, shown in the graphs of section 3, was in 1945 and not in 1943 and that the decline would perhaps have been more moderate. However, this would not significantly change the picture of this period. For the rest of the period, empirical evidence suggests that income assessment was made yearly.

12 There were eight wealth brackets between 1936 and 1958, eleven between 1959 and 1976 and eight between 1977 and 1982. The minimum wealth threshold was 100 escudos between 1936 and 1944, 500 between 1945 and 1958, 5,000 between 1959 and 1976 and 100,000 between 1977 and 1982 . 
FIGURE 3

CHANGES IN TOP INCOME SHARES

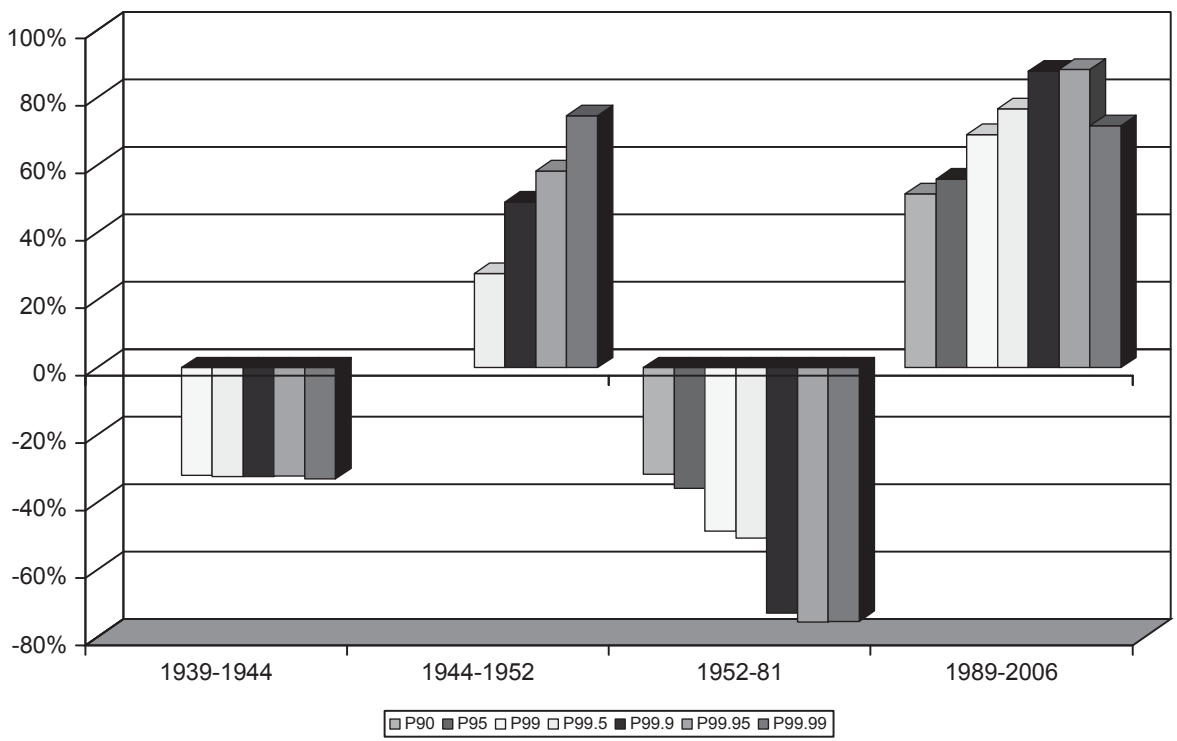

Source: Table A1.

The coverage of the source is very high throughout the whole period under analysis. It was above 60 per cent of deceased people till the mid 1950s, and increased from then on, to fluctuate between 80 and 90 per cent since the mid 1960s. These high coverage rates indicate that almost all the decedents who left some legacy to their heirs were covered by this tax.

The source provides the total wealth of the decedents minus tax exemptions, distributed among different wealth brackets. The tax statistics also provide information on tax exemptions and people exempt from paying taxes, classified into different brackets according to their wealth. These have been added to the taxed wealth and individuals and the resulting figures have been used to estimate the series.

With regard to the cadastral valuation of real estate, the possible distortions that could be introduced by this system would not be very significant because wealth underestimation would affect both the numerator and the denominator (total reference wealth) and the possible biasing effects would be counterbalanced.

The sample of observations from the estate tax is clearly biased in terms of age. The usual way to correct this is the estate multiplier method, which involves dividing the sample into different age groups and dividing each of them according to its mortality rate. Unfortunately, Portuguese tax sources 
FIGURE 4

TOP INCOME SHARES OVER 10 PER CENT (1936-1999)

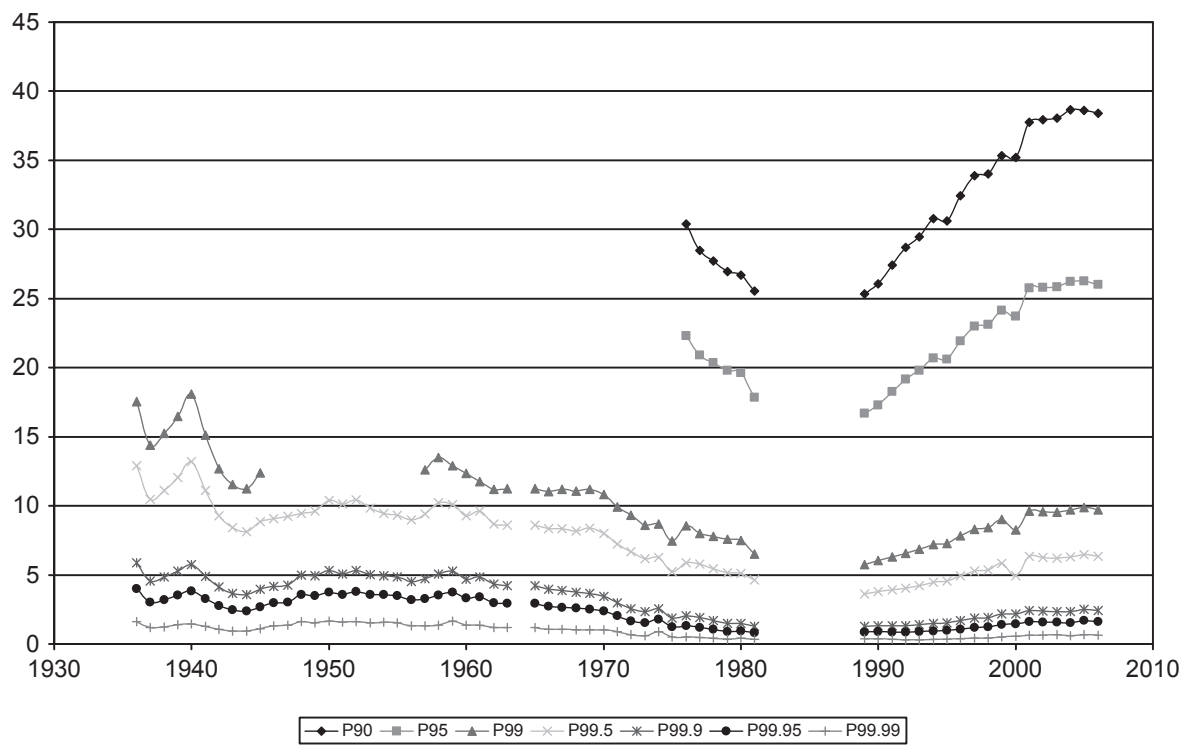

Source: Table A1.

do not provide the age of the decedents, and the measures of inequality presented refer to the deceased and not to the living population. Given that, in general terms, people tend to increase their wealth throughout their lives, the estate tax observations are likely to miss the relatively young and poor people and, then, to understate the level of the TWS. In this regard, other case studies show ambiguous outcomes on the possible distortions derived from the non-application of the estate multiplier method. In France and Sweden, the age bias of this kind of sample has had a minimal impact on wealth concentration estimations, whereas in the United Kingdom, it was sizeable (Piketty et al. 2006; Roine and Waldenström 2007; Atkinson et al. 1989).

\section{THE FACTS}

Several different periods may be distinguished in the evolution of Portuguese TIS and TWS. First of all, the Second World War seems to have had a significant impact on TIS. Although Portugal was neutral during the war, the conflict may have eroded TIS until 1945. Subsequently, the situation changed and by the early 1950s, TIS had recovered their pre-war values. 
FIGURE 5

TOP INCOME SHARES OVER 1 PER CENT (1936-1999)

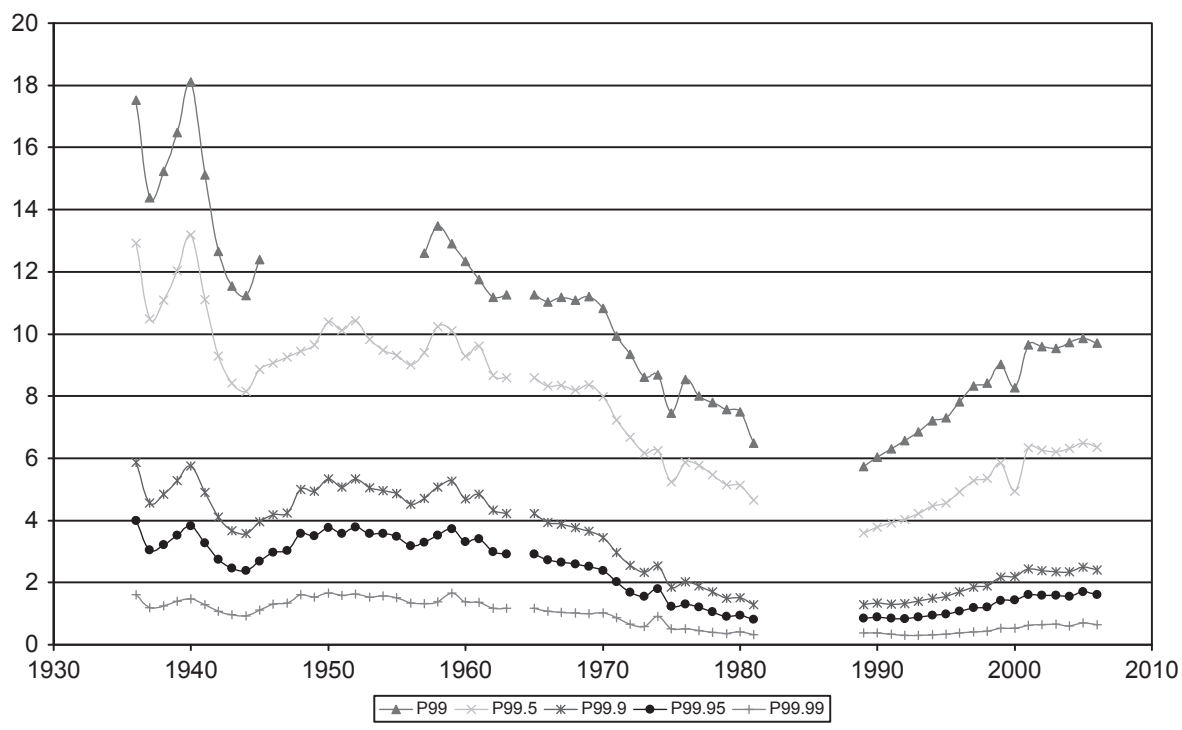

Source: Table A1.

In contrast, TWS remained unaffected by the conflict, following an increasing trend that lasted at least until the mid 1950s. The second period was characterized by a significant decrease in both TIS and TWS. After several years of relative stability of TIS and increasing wealth concentration, from the late 1950s onwards both magnitudes fell substantially until 1981. Finally, the third period, from 1989 onwards (for which there is no information on wealth shares), was again characterized by an increase in TIS. The next paragraphs describe these changes in more detail.

\subsection{Top Income Shares}

As can be seen in Figure 3, TIS fell by 30 per cent between 1939 and 1944 . This decrease was quite similar for all the fractiles for which information is available (top 1 per cent and above). The recovery of TIS after the Second World War also affected all fractiles, but was more intense for those located at the end of the income distribution. This meant not only an increase in inequality between the very rich and the rest of the population, but also a wider dispersion within the richest 1 per cent. Later, from the early 1950s to the early 1980s, TIS declined considerably. The decrease between 1952 and 
FIGURE 6

TOP INCOME SHARES OVER 0.1 PER CENT (1936-1999)

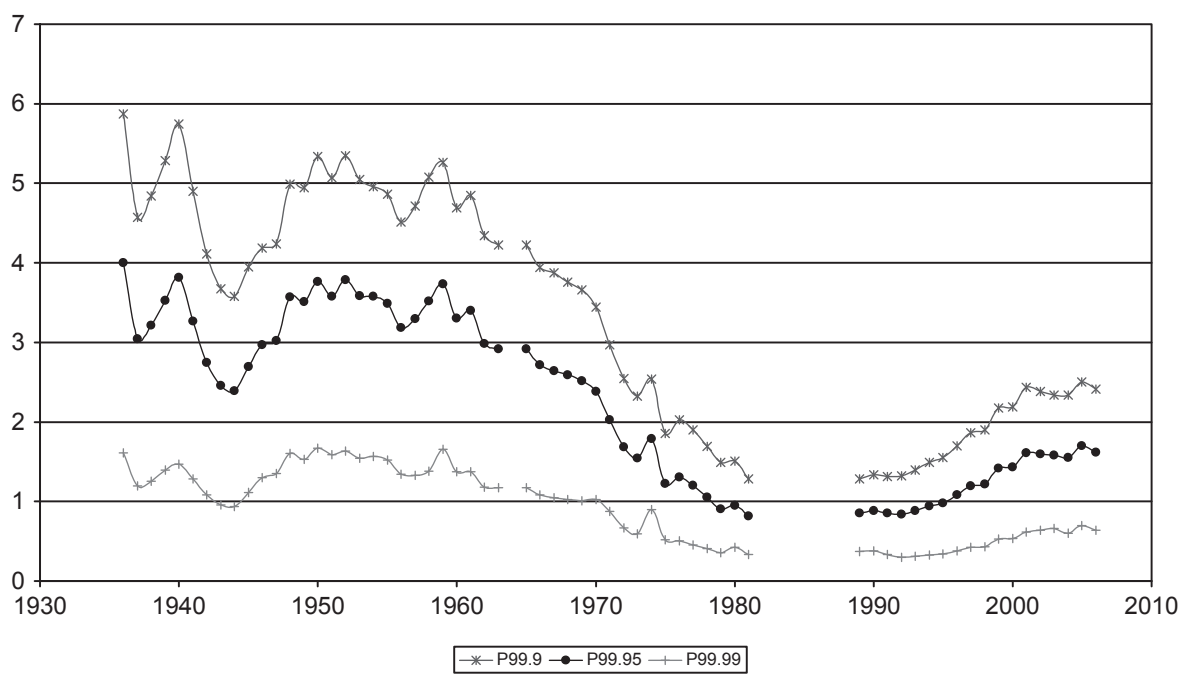

Source: Table A1.

1981 was again higher for those fractiles located at the end of income distribution, that is, there was a process of income convergence within the richest 1 per cent ${ }^{13}$. The lack of statistical data makes it impossible to discern what happened between 1981 and 1989, but, after this parenthesis, TIS increased until the end of the period under study. To observe these trends in more detail, Figures 4, 5 and 6 show the evolution of different TIS from 1936 onwards. Indeed, once the shock of the Second World War had been overcome, the most outstanding feature of the different figures is the huge decline in TIS that took place from the late 1950s to the 1980 s and its increase during the last two decades.

Figure 7 shows different ratios that reveal how many times richer (on average) tax units from the upper percentile of each ratio were than tax units from the lower one. The top 1 per cent is taken as reference because it is the largest share for which information is available for almost all years. Increases in the different ratios indicate an increasing dispersion among the very rich and vice versa. As can be seen in this figure, the different ratios evolved in the same direction. There was a relative stability until the mid 1940s, while from then to the late 1950s there was a process of slight

13 This last conclusion does not involve the top 5\% and 10\% shares because they are only available from 1976 onwards. 
FIGURE 7

PERCENTILE RATIOS (1936-1999)

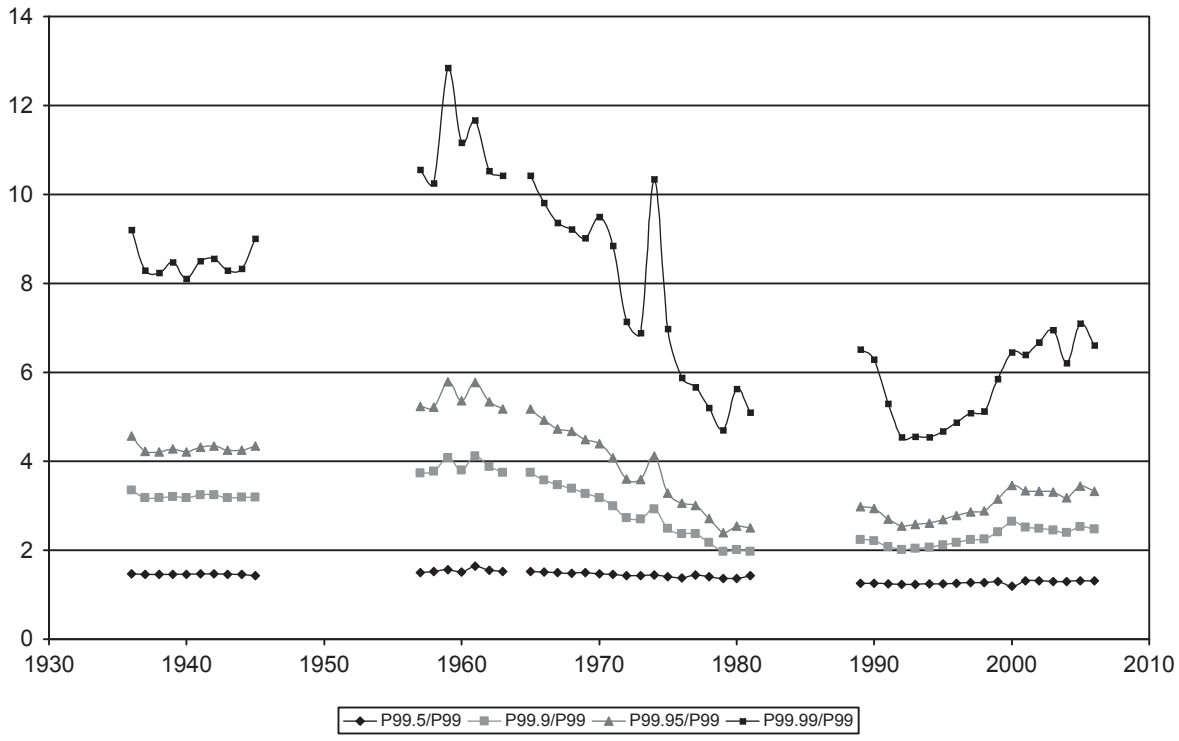

Source: Table A1.

divergence; however, data for this period are not complete and it is only possible to compare 1945 with 1957 . From the early 1960 s to the late 1970 s there was a significant convergence process. From the late 1980s to the early 1990s the ratios fell and they increased again until 2005. The ratio P99.99/ P99 is perhaps the most appropriate for characterizing the dispersion between the very rich. Until the mid 1940s the top 0.01 per cent was around eight times richer than the top 1 per cent, and in 1959 this ratio reached its historical maximum (12.8). From then onwards, it began to fall dramatically, and in 1979 , the top 0.01 per cent was only 4.7 times richer than the top 1 per cent. Nevertheless, in 1974, this ratio peaked at almost 11, during a short but intense rise-and-fall movement that could be related to the major political changes of that year ${ }^{14}$. In 1989 , the ratio was 6.5 , it fell to 4.5 in 1992 and it increased again to 7 in 2005.

Figure 8 compares the top 1 per cent income shares of nine developed countries with the new series. As may be seen in the graph, there is a common

14 The top 0.01 per cent is the only group that increased its income share in 1974 , because the P99-99.99 income share decreased in that year. This could be related with a more severe income assessment of some very rich individuals that only occurred in 1974. 
FIGURE 8

TOP 1 PER CENT INCOME SHARES

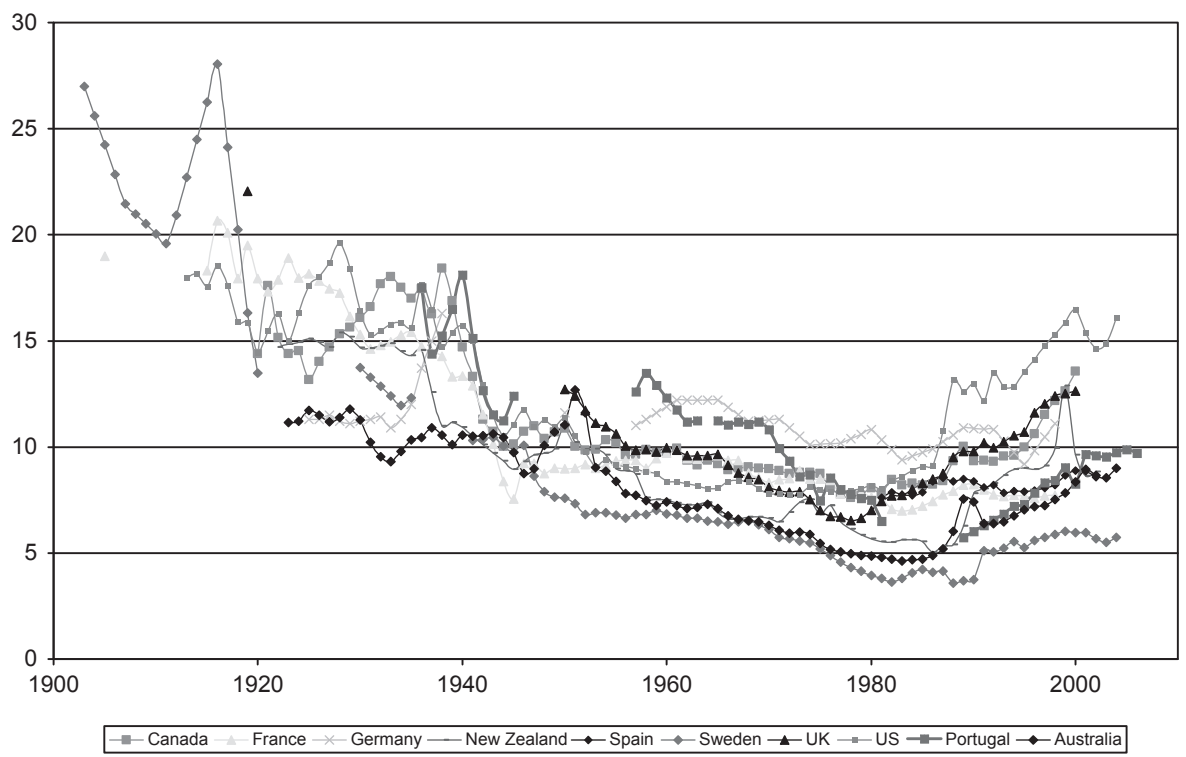

Source: Leigh (2006) and Table A1.

long-term decline in the series until the mid 1970s. It can also be seen that the shock of the Second World War provoked a significant decline in the top 1 per cent income shares of most countries. However, unlike what occurred in other countries, TIS in Portugal, Australia and New Zealand recovered their pre-war values in the early $1950 \mathrm{~s}^{15}$.

After the mid 1970s, whereas TIS increased in the Anglo-Saxon countries, they remained more or less stable in other countries (Piketty and Saez 2006). Once again, Portugal seems to have bucked this stylized trend because, at least from the late 1980s onwards, TIS in Portugal clearly increased.

The comparison of TIS levels among the different countries may be more problematic because of the disparity in the tax systems and their accuracy. Taking this into account, it seems that Portugal was a «member» of the high TIS group until the 1970s, but it became a low TIS country from the 1990s onwards. In this regard, contemporary Portugal has usually been included among those European countries with a higher degree of inequality (Rodrigues 1999). However, TIS seem to indicate that the very rich are not at

15 In the case of Portugal, there are no data for the top 1 per cent income shares for the post-war period, but this recovery can be seen in the evolution of the upper fractiles. 
FIGURE 9

CHANGES IN TOP WEALTH SHARES (1936-1982)

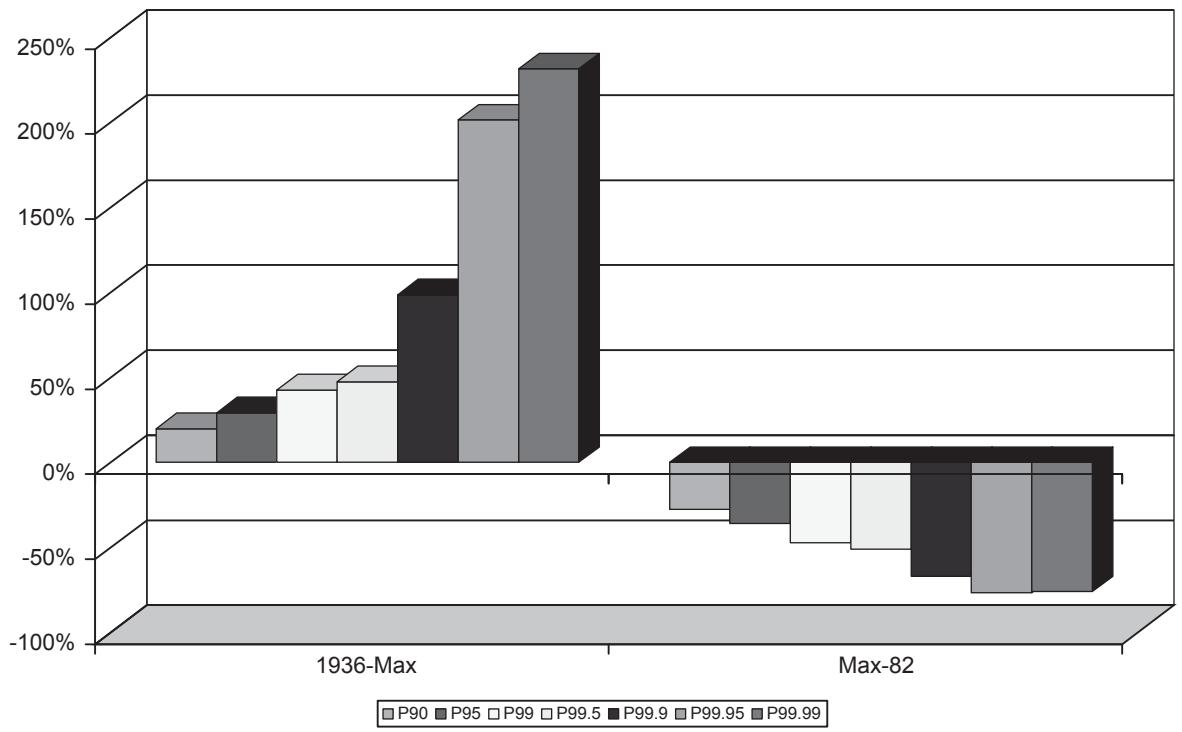

Source: Table A2.

the root of this phenomenon, and that it may, instead, be a poverty-related issue, because the Portuguese TIS have been low in comparative terms during the last two decades.

\subsection{Top Wealth Shares}

As may be seen in Figure 9, the evolution of TWS may be divided into two different periods. Until the mid 1950s or the early 1960s (depending on the share), they increased considerably, especially in the case of the richest fractiles. This is consistent with both a process of increasing inequality between the very rich and the rest of the population and a process of wealth divergence within the very rich group. The situation changed subsequently and TWS declined continuously until at least 1982. The decrease in the TWS was again more intense in the case of the richest fractiles, that is, there was a process of decreasing inequality between the very rich and the rest of the population and also a process of wealth convergence within the very rich group.

Figures 10 and 11 show the yearly evolution of TWS, which followed an inverted U-curve with maximum values of wealth concentration during 
FIGURE 10

TOP WEALTH SHARES (1936-1982)

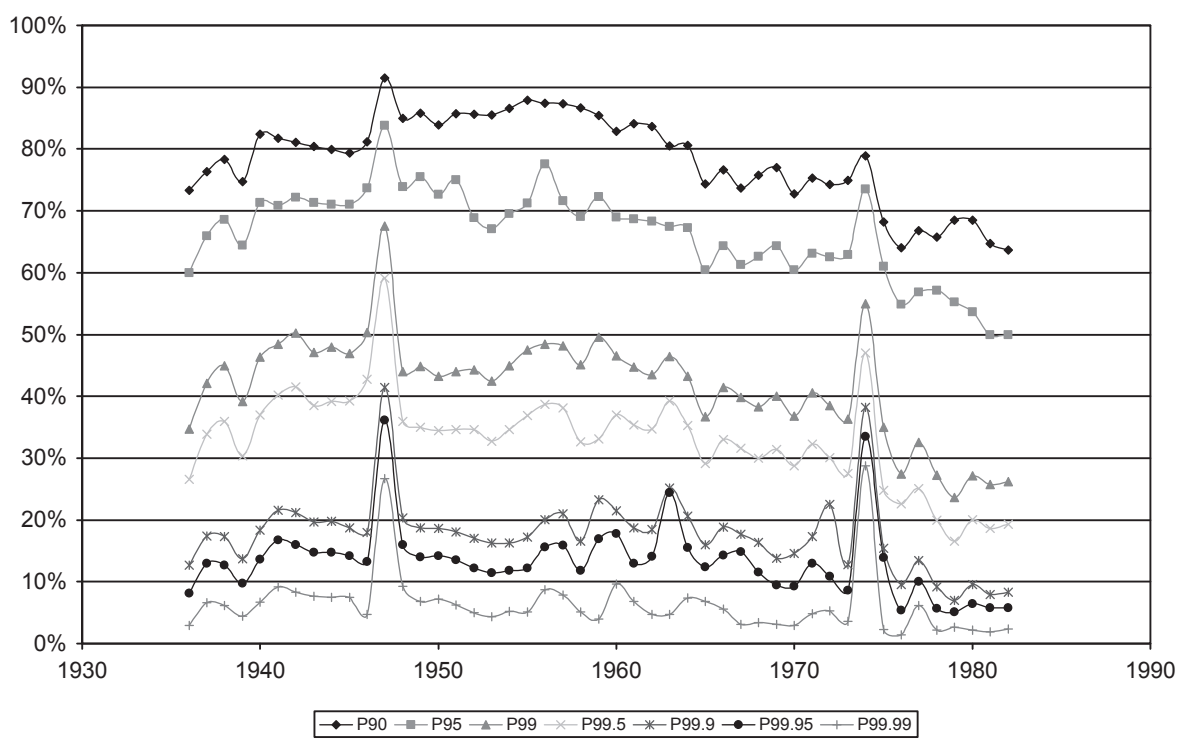

Source: Table A2.

the mid 1950s and early 1960s. These figures also show two short but very intense increases in TWS in 1947 and 1974, which can be explained by the impact that the death of a few very rich individuals may have had on this kind of estimation. In this sense, in both 1947 and 1974, two extremely rich citizens died in the district of Lisbon, which explains these two peaks $^{16}$.

In the case of wealth concentration, the Portuguese experience is somewhat exceptional in a comparative perspective, as may be seen in Figure 12. In most other countries (with the partial exception of Switzerland), there was a long-term decline in wealth concentration throughout the $20^{\text {th }}$ century, whereas in Portugal, it increased till the mid $20^{\text {th }}$ century to decline afterwards. However, from a longer-term perspective, the evolution of wealth concentration in France throughout the $19^{\text {th }}$ and $20^{\text {th }}$ centuries also followed an inverted U-curve. Accordingly, the evolution of Portuguese wealth concentration might fit the pattern of the most industrialized countries, although with a half-century delay.

16 The impact of the extremely rich person's death on these estimations is also observable in other countries such as the United Kingdom during the 1970s (see Figure 12). 
FIGURE 11

TOP WEALTH SHARES (1936-1982)

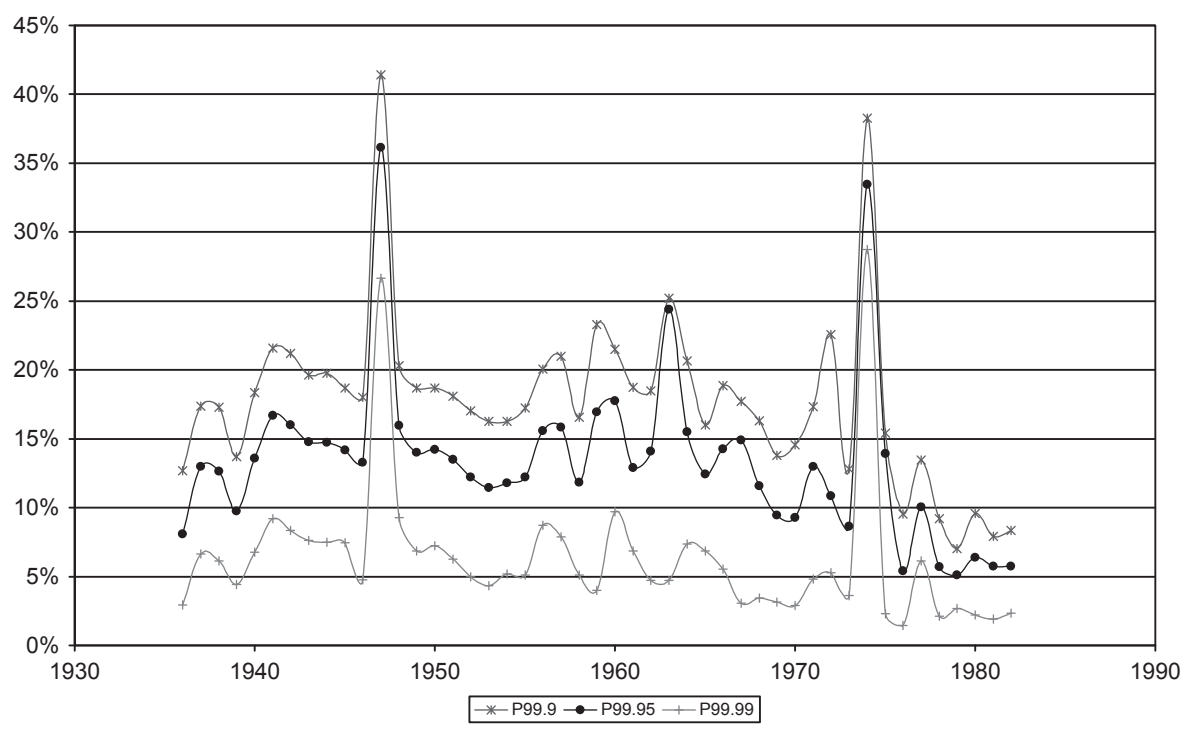

Source: Table A2.

\section{BEHIND THE FACTS}

It is not possible to offer a complete account of the reasons behind the detected trends in Portuguese TIS and TWS here. However, some general considerations may serve as a guide for a future research agenda. Most studies related to TIS defend the idea that the main explanation for the decline of TIS until the 1970s was associated with the shocks of the two World Wars and also with the role of progressive taxation and other public policies. As noted above, Portuguese TIS began to decline in the 1950s, and the Salazar regime was not as committed to the implementation of progressive policies as other developed countries. Thus, we may look for alternative explanations to understand the evolution of TIS, such as the impact of the extraordinary economic growth of the post-war decades.

In this sense, one of the main features that differentiated the periods after 1950 from the previous decades in Portugal was the rapid structural change from an agrarian economy to an industrial and service-oriented one, as may be seen in Table 2. The original Kuznets hypothesis relates the process of structural change to the existence of an inverted U-curve in the evolution of income inequality. However, income inequality can be measured in different ways. 
FIGURE 12

TOP 1 PER CENT WEALTH SHARE

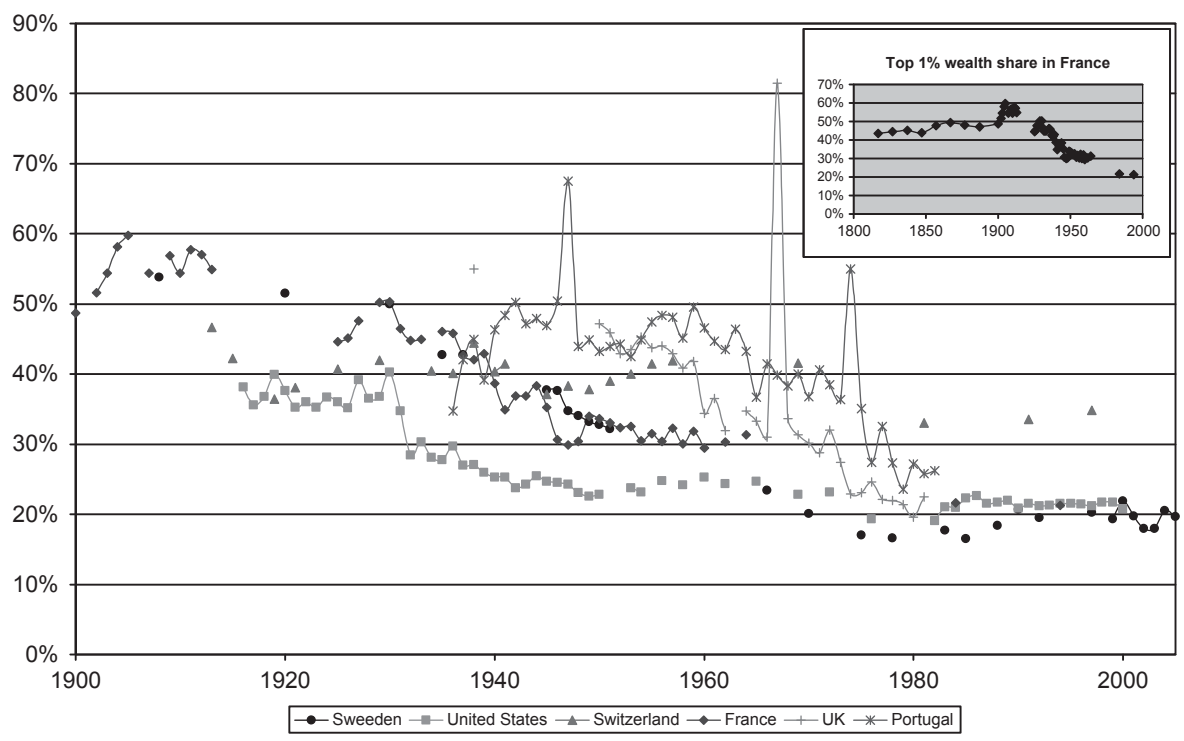

Source: Roine and Waldenström (2009) for Sweden; Kopczuk and Saez (2004) for the United States; Dell et al. (2005) for Switzerland; Piketty et al. (2006) for France; Atkinson et al. (1989) for the United Kingdom and Table A2.

A measure of income inequality with high population coverage is likely to follow an inverted U-curve during the transition from an agrarian economy to a modern one, for the reasons argued by Kuznets (1955). In this sense, Lains et al. (2008) have confirmed the existence of an inverted U-curve during the Portuguese dictatorship econometrically (with a maximum value in 1959) through the estimation of wage inequality. In contrast, a partial income inequality measure, such as TIS, is likely to show a decline in inequality during this process of transition and for the same reasons ${ }^{17}$. This is due to the fact that, although the progressive transition of the labour force to better paid jobs could increase inequality within the lower classes (which were more homogeneous in terms of their incomes at the beginning of the process), it may also increase the share of incomes accruing to the bottom fractiles, a process which might prevent top income share increases. This seems to have been the case in Portugal, at least till the 1980s (if the fluctuations associated with the Second World War are excluded). TIS would only increase again after the early 1990s, when the process of structural change was almost complete.

17 In fact, the original formulation of the Kuznets curve predicts a decline of the top 20 per cent income share from the very beginning of the process of transition (see Kuznets 1955, p. 15). 
TABLE 2

MALE LABOUR FORCE (1911-1950) AND TOTAL EMPLOYMENT (1960-1990)

\begin{tabular}{|l|c|c|c|c|}
\hline & Agriculture (\%) & Industry (\%) & Services (\%) & Total male labour force \\
\hline & & & & $\mathbf{0 0 0}$ \\
\hline $\mathbf{1 9 1 1}$ & 61.0 & 21.7 & 17.3 & 1,629 \\
\hline $\mathbf{1 9 2 0}$ & 60.9 & 21.2 & 17.9 & 1,691 \\
\hline $\mathbf{1 9 3 0}$ & 60.9 & 20.7 & 18.4 & 1,967 \\
\hline $\mathbf{1 9 4 0}$ & 57.8 & 21.0 & 21.1 & 2,241 \\
\hline $\mathbf{1 9 5 0}$ & 53.8 & 24.6 & 21.6 & 2,562 \\
\hline $\mathbf{1 9 6 0}$ & 43.1 & 28.2 & 28.7 & 2,713 \\
\hline $\mathbf{1 9 7 0}$ & 27.6 & 33.9 & 38.6 & 2,263 \\
\hline $\mathbf{1 9 8 0}$ & 19.2 & 37.7 & 43.1 & 2,544 \\
\hline $\mathbf{1 9 9 0}$ & 13.1 & 37.3 & 49.6 & 2,476 \\
\hline
\end{tabular}

Sources: Lains (2003b, p. 15) for 1911-1950 and Valério (2001, p. 164) for 1960-1990.

Another event, which may help to explain the decline of TIS from the high levels of the first half of the $20^{\text {th }}$ century, is the skilled labour-intensive growth process experienced by most countries. A larger share of increasingly skilled workers is required for the economy to continue growing and these workers have to be remunerated accordingly. The outcome of this process is the increasing income share of the middle classes that has characterized the mass consumption society, and must also have contributed to the erosion of TIS. In this regard, this process would have a higher incidence once a country has already overcome the first stages of the Kuznets curve, and it would increase the period of time of declining TIS.

Compared with the effects of structural change, political factors seem to have had a minor impact on Portuguese TIS and TWS. During most of the dictatorial period, TIS and TWS declined. In addition, it is surprising to see that the evolution of the different TIS and TWS was not especially sensitive to the profound political and social changes that occurred after the Revoluçao dos cravos of 25 April 1974 and the transition to democracy. TIS and TWS declined during the early years of the democratic era, but at the same pace as during the pre-revolutionary period. This finding is highly relevant from the point of view of Portuguese history, since the country's upper classes did not seem to have been particularly damaged by the revolutionary process. What is more, during the democratic era, a decrease of TIS through the political channel might have been expected. Once the population obtained a political voice, a more progressive political agenda might have 
tended to redistribute income and thus reduce TIS. However, just the opposite happened, suggesting a situation of imperfect democracy, with forces such as lobby interests limiting the strength of voters' demands.

\section{CONCLUDING REMARKS}

This paper has presented a new long-term series for the evolution of TIS and TWS in Portugal from 1936 onwards. The Portuguese case study may help to enlarge the current comparative inequality database developed with the methodology established by Piketty (2001). Available comparative information regarding income inequality has been compiled since the 1950s (Deininger and Squire 1996), but the methodologies used differ across countries and over time, which seriously limits the consistency of the studies based on these databases. In contrast, TIS and TWS are all estimated from tax sources, following the same methodology, and, in many cases, they provide information for the whole of the $20^{\text {th }}$ century ${ }^{18}$.

TIS in Portugal declined during the Second World War and recovered during the post-war period, whereas TWS increased till the mid 1950s. From the mid 1950s to the early 1980s TIS and TWS declined sharply, and then, during the last decade of the $20^{\text {th }}$ century, TIS increased again. This pattern is quite similar to the experience of other countries: the decline of TIS during the «Golden Age» has been observed in most other cases, and their increase during the last two decades seems to put Portugal on a par with the experience of the Anglo-Saxon countries.

The reasons behind the trends observed in Portuguese TIS and TWS remain poorly understood. Here, it has been suggested that the factors governing the evolution of TIS were economic and not political. In this sense, during most of the dictatorship, the TIS declined, and the transition to democracy seems to have had a minor impact on TIS trends. On the other hand, the rapid structural change that occurred from the 1950s onwards seems to be a key factor in an understanding of the Portuguese distributive pattern.

\section{STATISTICAL SOURCES}

INSTITUTO NACIONAL DE ESTATÍSTICA (1936-1966): Anuário estatístico das contribuiçoes e impostos.

INSTITUTO NACIONAL DE ESTATÍSTICA (1967-1982): Estatísticas das contribuiçoes e impostos.

${ }^{18}$ Although comparability problems should not be forgotten, see Atkinson (2007) and Piketty (2007). 
INSTITUTO NACIONAL DE ESTATÍSTICA (1989-1999): Estatísticas das receitas fiscais.

INSTITUTO NACIONAL DE ESTATÍSTICA (1930-2000): Recenseamento geral da populaçao.

\section{REFERENCES}

Alvaredo, F. (2008): «Top Incomes and Earnings in Portugal 1936-2004». PSE Working Papers no.17.

Alvaredo, F. (2009): «Top Income and Earnings in Portugal 1936-2005». Explorations in Economic History 46 (4), pp. 404-417.

Atkinson, A. (2007): «Measuring Top Incomes: Methodological Issues», in A. Atkinson, and T. Piketty (eds), Top Incomes over the Twentieth Century: A Contrast Between Continental European and English Speaking. Oxford: Oxford University Press, pp. 18-42.

AtKinson, A.; Gordon, J., and Harrison, A. (1989): "Trends in the Shares of Top Wealth-Holders in Britain 1923-1981». Oxford Bulletin of Economics and Statistics 51 (3), pp. 315-332.

Atrinson, A., and Piketty, T. (2007): Top Incomes over the Twentieth Century: A Contrast between Continental European and English Speaking Countries. Oxford: Oxford University Press.

Batista, D.; Martins, C.; Pinheiro, M., and Reis, J. (1997): «New Estimates for Portugal's GDP, 1910-1958». História Económica 7, p. 88.

DeININGER, K., and Souire, L. (1996): "A New Data Set Measuring Income Inequality». The World Bank Economic Review 10 (3), pp. 565-591.

Dell, F.; Piketty, T., and SAez, E. (2005): "Income and wealth concentration in Switzerland over the 20th century», CEPR Discussion Papers no. 5090.

Feenberg, D., and Poterba, J. (1993): «Income Inequality and the Incomes of Very High Income Taxpayers: Evidence from Tax Returns». NBER. Working paper no. 4229.

GuIlERA, J. (2008): "Top Income Shares in Portugal Over the Twentieth Century». Working paper E08/195, Documents de treball de la Facultat de Ciències Econòmiques i Empresarials. Col-lecció d'Economia, Universitat de Barcelona.

KopczuK, W., and SAEZ, E. (2004): «Top Wealth Shares in the United States: 1916-2000: Evidence from Estate Tax Returns». NBER Working Papers no. 10399.

KuZNETS, S. (1953): Share of Upper Income Groups in Income and Savings. New York: National Bureau of Economic Research.

KuZNETS, S. (1955): «Economic Growth and Income Distribution». The American Economic Review 45 (1), pp. 1-28.

Lains, P. (2003a): «Catching up to the European core: Portuguese Economic Growth, 1910-1990». Explorations in Economic History 40 (4), pp. 369-386.

Lains, P. (2003b): «Portugal's Growth Paradox, 1870-1950». Working Paper 135, Faculdade de Economia, Universidade do Porto.

Lains, P.; Gomes, E., and Guilera, J. (2008): «Are Dictatorships More Unequal? Economic Growth and Wage Inequality during Portugal's Estado Novo, 1944-1974». Working Papers in Economic History WP 08-08, Universidad Carlos III, Departamento de Historia Económica e Instituciones.

Leigh, A. (2007): «How Closely Do Top Income Shares Track Other Measures of Inequality?». Economic Journal, Royal Economic Society 117 (524), pp. 619-633.

Leitao, L. (2001): «Evoluçao e Situaçao da Reforma Fiscal». Ciencia e Técnica Fiscal 387 , pp. 7-47. 
Oliveira Marques, A. H. (1991): História de Portugal. Lisboa: Imprensa Nacional — Casa da Moeda.

Piketty, T. (2001): Les Hauts Revenues en France au XXè siècle - Inegalités et Redistributions, 1901-1998. Paris: Grasset.

PiketTy, T. (2007): «Top Incomes over the Twentieth Century: A Summary of the Main Findings», in A. Atkinson, and T. Piketty (eds), Top Incomes over the Twentieth Century: A Contrast Between Continental European and English Speaking Countries. Oxford: Oxford University Press, pp. 1-17.

Piketty, T., and Saez, E. (2006): «Income Inequality in the United States, 1913-1998». National Bureau of Economic Research Working Paper 8467.

Piketty, T.; Postel-Vinay, G., and Rosenthal, J. L. (2006): "Wealth Concentration in a Developing Economy: Paris and France, 1807-1994». American Economic Review 96 (1), pp. 236-256.

Pinheiro, M. (1997): Séries Longas para a Economia Portuguesa. Pós II Guerra Mundial, vol. I - Séries Estatísticas. Lisbon: Banco de Portugal.

RibeIro, J. (1968): «A Contra-reforma Fiscal», in A Reforma Fiscal. Coimbra: Coimbra Editora.

Rodrigues, C. F. (1999): «Repartição do Rendimento e Pobreza em Portugal [1994/95] — Uma comparação entre o Painel Dos Agregados Familiares e o Inquérito aos Orçamentos Familiares». Revista De Estatística V (1), pp. 117-142.

Roine, J., and WALDENSTRÖM, D. (2007): "Wealth Concentration over the Path of Development: Sweden 1873-2005». Working Paper Series in Economics and Finance no. 677, Stockholm School of Economics.

Roine, J., and WALDEnStröm, D. (2009): «Wealth Concentration over the Path of Development: Sweden, 1873-2006». Scandinavian Journal of Economics 111 (1), pp. 151-187.

Valerio, N. (1994): As Finanças Públicas Portuguesas entre as duas Guerras Mundiais. Lisbon: Ediçoes Cosmos.

Valerio, N. (2001): Estatísticas Históricas Portuguesas. Lisbon: Instituto Nacional de Estatística.

\section{APPENDIX 1}

Figure A1 shows the distributional functions of the incomes of the different tax units under different hypotheses in 1963 and 1965. The vertical axis shows the percentage of income (relative to the total income assessed) accumulated through tax units, which are shown in the horizontal axis. The first function (1) shows the distributional function of total incomes in 1963, whereas the second function shows the distributional function of taxable incomes in the same year. As may be seen in the graph, when deductions are subtracted, the distributional function moves upwards. This implies that deductions were progressive to income. For 1965 information is only available for taxable income, which is shown in the third function. This has almost the same shape as taxable income in 1963. In order to allocate deductions among the income of different tax units for 1965, two different scenarios have been simulated and compared with the situation in 1963. 
FIGURE A1

ALLOCATION OF 1964-1981 DEDUCTIONS

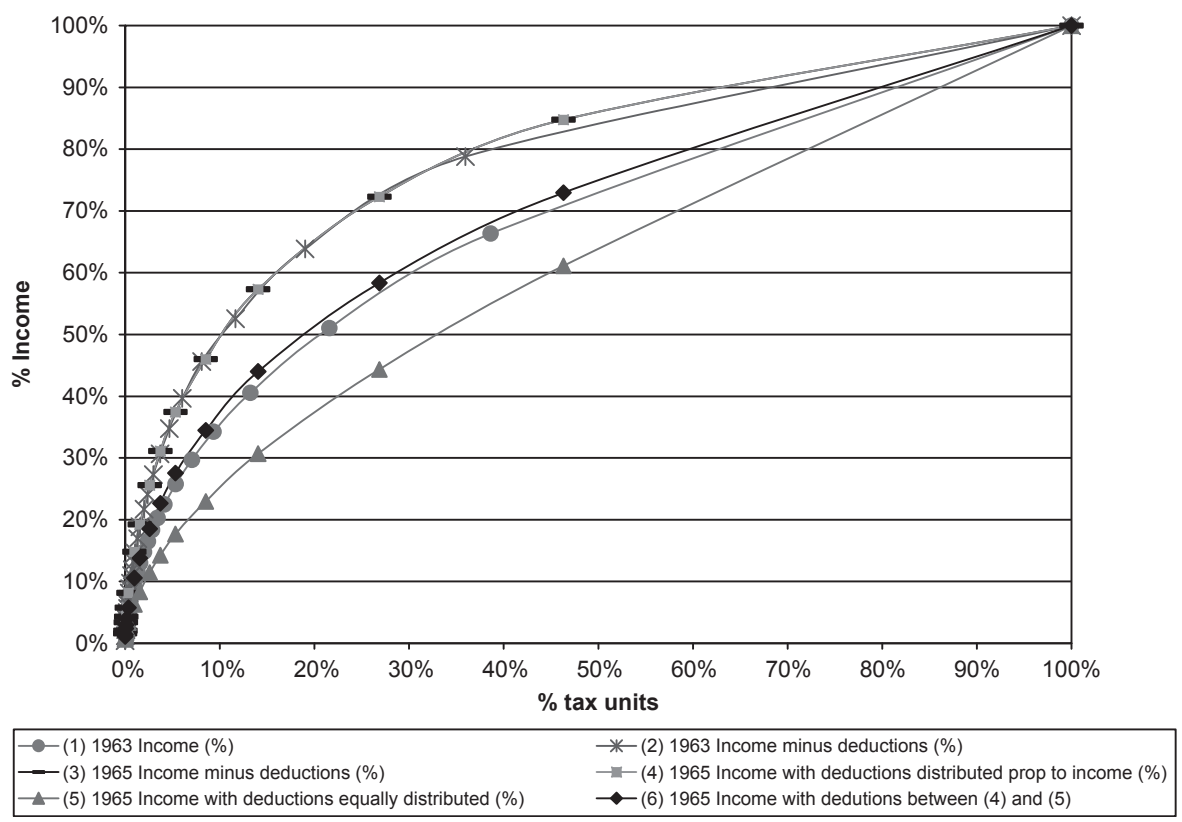

Source: Own elaboration from Portuguese tax statistics.

The fourth function shows the distributional function of incomes when deductions are allocated proportionally to income, whereas the fifth function shows the distributional function when deductions are equally distributed among all tax units. Not surprisingly, the third and fourth functions have exactly the same shape, because the fourth function is the outcome of allocating deductions in a proportional system. On the other hand, the fifth function swung downwards in line with the progressive character of the deductions. As may be seen, the distributional function of total incomes for 1963 is between these two last scenarios. The sixth function is the arithmetic average of the proportional (4) and progressive (5) scenarios and has been the alternative chosen to allocate deductions for its proximity to the total income function of 1963 (1).

\section{APPENDIX 2}

This appendix analyses the reasons why two series, which were estimated with the same sources and methodology, show different outcomes. There 
are four main differences between our series and those of Alvaredo: the reference income definition, the method used to add deductions to taxable income, the transparency in the treatment of the sources and the adjustment of TIS levels in order to have long-term consistent series.

Alvaredo's reference income is defined as wages and salaries from National Accounts net of effective social security contributions, plus 50 per cent of social transfers, plus 66 per cent of unincorporated business income plus all non-business, non-labor income reported on tax returns. He is able to estimate this figure from 1989 onwards, that is around 60 per cent of total GDP, which is the percentage he applies backwards to calculate the total income reference. The difference between our 80.36 per cent and Alvaredo's 60 per cent is the reason why his series have persistently higher levels than our non-adjusted ones, as may be seen in Figure A2. Some inconsistencies should, however, be highlighted here. As seen in Figure 2, the ratio PSI/ GDP falls intensively between 1989 and 2000 from 76 to 65 per cent of GDP. It is difficult to believe that the income reference estimated by Alvaredo remained constant around 60 per cent. Finally, given the high variability of the PSI/GDP ratio from the mid 1960s onwards, it is not reasonable to assume a constant rate for this period. Taking all these facts into account, our method of defining the total income reference seems more appropriate.

From 1964 to 1981, to add deductions to taxable income, Alvaredo (2008) adds family deductions proportionally to population and the others proportionally to income. This does not constitute an important difference between the two methods. However, if we compare Alvaredo's series with our non-adjusted ones, in our series, a sizeable discontinuity appears between 1963 and 1965 (see Figure A2). It could seem that this discontinuity was associated with our inappropriate method of adding deductions to taxable income, but the real cause of this discontinuity is the fiscal reform of the mid 1960s. This major fiscal reform is totally ignored by Alvaredo (2008), and it is the reason behind the discontinuity in our non-adjusted series. What is more surprising is that Alvaredo's series are fairly stable during the 1960s and this is due to the fact the he does not show all the information available. Tax sources allow yearly income shares above the top 0.5 per cent to be estimated and, with the parentheses of 10 years, also the top 1 per cent. Alvaredo, however, only shows the TIS above 0.1 per cent. In fact, Alvaredo's table A, column 4 illustrates that he could also have estimated the top 0.5 and 1 per cent income shares. If those income shares had been estimated, the discontinuities would have appeared ${ }^{19}$.

19 Alvaredo's method of adding deductions is more proportional to population that ours, and this is the reason why these discontinuities do not appear in his top 0.1 per cent income share. However, they would have had an important impact on the top 0.5 and 1 per cent income share, if he had calculated them. 
FIGURE A2

TOP INCOME SHARES: ALVAREDO VS. GUILERA

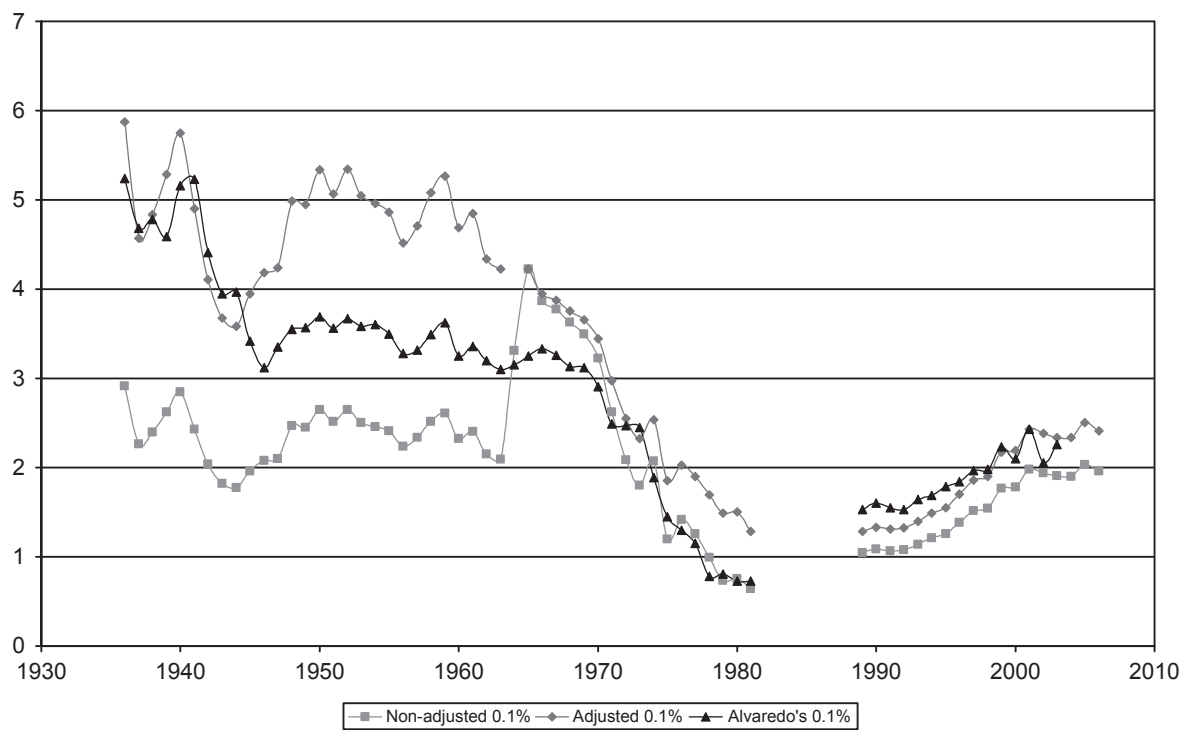

Sources: Table A1, Guilera (2008) and Alvaredo (2008).

Finally, the levels in our series have been adjusted in 1963, 1980 and 1990 in order to correct the discontinuities of our series (see text). The break of the 1960s does not appear in Alvaredo's series for the reasons explained above. The discontinuity of the 1980s in Alvaredo's series is not adjusted, and this leads to unrealistic results when they are compared with the alternative sources available such as HIES. Whereas HIES show a slight decrease in the top 10 per cent income share, Alvaredo's series show a sizeable increase in TIS during the 1980s.

The differences between the two estimations indicate the improved reliability and long-term consistency of our series compared with those of Alvaredo. 


\section{APPENDIX 3}

Top income and wealth shares.

TABLE A1

PORTUGUESE TOP INCOME SHARES (\%)

\begin{tabular}{|c|c|c|c|c|c|c|c|}
\hline & P90 & P95 & P99 & P99.5 & P99.9 & P99.95 & P99.99 \\
\hline 1936 & & & 17.52 & 12.92 & 5.87 & 4.00 & 1.61 \\
\hline 1937 & & & 14.39 & 10.48 & 4.57 & 3.04 & 1.19 \\
\hline 1938 & & & 15.23 & 11.10 & 4.84 & 3.21 & 1.26 \\
\hline 1939 & & & 16.49 & 12.03 & 5.28 & 3.52 & 1.40 \\
\hline 1940 & & & 18.11 & 13.19 & 5.75 & 3.81 & 1.47 \\
\hline 1941 & & & 15.12 & 11.11 & 4.90 & 3.27 & 1.29 \\
\hline 1942 & & & 12.67 & 9.29 & 4.11 & 2.75 & 1.08 \\
\hline 1943 & & & 11.54 & 8.41 & 3.67 & 2.46 & 0.96 \\
\hline 1944 & & & 11.24 & 8.15 & 3.58 & 2.39 & 0.94 \\
\hline 1945 & & & 12.39 & 8.86 & 3.95 & 2.69 & 1.12 \\
\hline 1946 & & & & 9.06 & 4.19 & 2.97 & 1.30 \\
\hline 1947 & & & & 9.25 & 4.24 & 3.02 & 1.35 \\
\hline 1948 & & & & 9.45 & 4.99 & 3.57 & 1.60 \\
\hline 1949 & & & & 9.64 & 4.95 & 3.51 & 1.53 \\
\hline 1950 & & & & 10.39 & 5.34 & 3.77 & 1.67 \\
\hline 1951 & & & & 10.13 & 5.07 & 3.57 & 1.59 \\
\hline 1952 & & & & 10.43 & 5.34 & 3.79 & 1.63 \\
\hline 1953 & & & & 9.82 & 5.04 & 3.58 & 1.54 \\
\hline 1954 & & & & 9.47 & 4.96 & 3.58 & 1.57 \\
\hline 1955 & & & & 9.30 & 4.86 & 3.49 & 1.52 \\
\hline 1956 & & & & 9.00 & 4.51 & 3.18 & 1.34 \\
\hline 1957 & & & 12.61 & 9.41 & 4.71 & 3.30 & 1.33 \\
\hline 1958 & & & 13.48 & 10.23 & 5.08 & 3.52 & 1.38 \\
\hline 1959 & & & 12.90 & 10.10 & 5.26 & 3.73 & 1.66 \\
\hline 1960 & & & 12.33 & 9.30 & 4.69 & 3.30 & 1.38 \\
\hline 1961 & & & 11.75 & 9.62 & 4.85 & 3.40 & 1.37 \\
\hline
\end{tabular}


TABLE A1 (Cont.)

\begin{tabular}{|c|c|c|c|c|c|c|c|}
\hline & P90 & P95 & P99 & P99.5 & P99.9 & P99.95 & P99.99 \\
\hline 1962 & & & 11.18 & 8.67 & 4.34 & 2.98 & 1.18 \\
\hline 1963 & & & 11.25 & 8.59 & 4.22 & 2.92 & 1.17 \\
\hline \multicolumn{8}{|l|}{1964} \\
\hline 1965 & & & 11.25 & 8.59 & 4.22 & 2.92 & 1.17 \\
\hline 1966 & & & 11.03 & 8.33 & 3.94 & 2.72 & 1.08 \\
\hline 1967 & & & 11.18 & 8.34 & 3.87 & 2.65 & 1.05 \\
\hline 1968 & & & 11.08 & 8.19 & 3.76 & 2.59 & 1.02 \\
\hline 1969 & & & 11.19 & 8.37 & 3.66 & 2.52 & 1.01 \\
\hline 1970 & & & 10.82 & 7.99 & 3.44 & 2.38 & 1.03 \\
\hline 1971 & & & 9.94 & 7.23 & 2.97 & 2.03 & 0.88 \\
\hline 1972 & & & 9.34 & 6.68 & 2.55 & 1.68 & 0.67 \\
\hline 1973 & & & 8.61 & 6.16 & 2.32 & 1.55 & 0.59 \\
\hline 1974 & & & 8.69 & 6.25 & 2.54 & 1.79 & 0.90 \\
\hline 1975 & & & 7.45 & 5.24 & 1.85 & 1.23 & 0.52 \\
\hline 1976 & 30.40 & 22.32 & 8.54 & 5.87 & 2.03 & 1.31 & 0.50 \\
\hline 1977 & 28.48 & 20.92 & 8.00 & 5.78 & 1.90 & 1.20 & 0.45 \\
\hline 1978 & 27.72 & 20.36 & 7.79 & 5.46 & 1.69 & 1.06 & 0.40 \\
\hline 1979 & 26.96 & 19.80 & 7.57 & 5.15 & 1.49 & 0.91 & 0.36 \\
\hline 1980 & 26.70 & 19.61 & 7.50 & 5.13 & 1.51 & 0.95 & 0.42 \\
\hline 1981 & 25.55 & 17.84 & 6.50 & 4.65 & 1.29 & 0.81 & 0.33 \\
\hline \multicolumn{8}{|l|}{1982} \\
\hline \multicolumn{8}{|l|}{1983} \\
\hline \multicolumn{8}{|l|}{1984} \\
\hline \multicolumn{8}{|l|}{1985} \\
\hline \multicolumn{8}{|l|}{1986} \\
\hline \multicolumn{8}{|l|}{1987} \\
\hline \multicolumn{8}{|l|}{1988} \\
\hline 1989 & 25.33 & 16.69 & 5.74 & 3.60 & 1.28 & 0.86 & 0.37 \\
\hline 1990 & 26.07 & 17.30 & 6.03 & 3.78 & 1.33 & 0.88 & 0.38 \\
\hline
\end{tabular}


TABLE A1 (Cont.)

\begin{tabular}{|l|l|l|l|l|l|l|l|}
\hline 1991 & 27.44 & 18.26 & 6.31 & 3.91 & 1.31 & 0.85 & 0.33 \\
\hline 1992 & 28.70 & 19.15 & 6.57 & 4.03 & 1.32 & 0.84 & 0.30 \\
\hline 1993 & 29.48 & 19.78 & 6.85 & 4.22 & 1.40 & 0.89 & 0.31 \\
\hline 1994 & 30.80 & 20.69 & 7.21 & 4.47 & 1.49 & 0.94 & 0.33 \\
\hline 1995 & 30.59 & 20.62 & 7.29 & 4.55 & 1.55 & 0.98 & 0.34 \\
\hline 1996 & 32.43 & 21.93 & 7.82 & 4.93 & 1.70 & 1.08 & 0.38 \\
\hline 1997 & 33.87 & 23.00 & 8.32 & 5.28 & 1.86 & 1.19 & 0.42 \\
\hline 1998 & 34.00 & 23.12 & 8.43 & 5.36 & 1.90 & 1.22 & 0.43 \\
\hline 1999 & 35.35 & 24.15 & 9.03 & 5.85 & 2.17 & 1.42 & 0.53 \\
\hline 2000 & 35.19 & 23.72 & 8.27 & 4.93 & 2.19 & 1.43 & 0.53 \\
\hline 2001 & 37.78 & 25.77 & 9.64 & 6.34 & 2.43 & 1.61 & 0.62 \\
\hline 2002 & 37.92 & 25.80 & 9.59 & 6.27 & 2.39 & 1.60 & 0.64 \\
\hline 2003 & 38.06 & 25.82 & 9.54 & 6.20 & 2.34 & 1.58 & 0.66 \\
\hline 2004 & 38.65 & 26.23 & 9.73 & 6.31 & 2.34 & 1.55 & 0.60 \\
\hline 2005 & 38.63 & 26.27 & 9.86 & 6.48 & 2.50 & 1.70 & 0.70 \\
\hline 2006 & 38.38 & 26.02 & 9.71 & 6.36 & 2.41 & 1.62 & 0.64 \\
\hline
\end{tabular}

Source: See text. 
TABLE A2

PORTUGUESE TOP WEALTH SHARES (\%)

\begin{tabular}{|c|c|c|c|c|c|c|c|}
\hline & P90 & P95 & P99 & P99.5 & P99.9 & P99.95 & P99.99 \\
\hline 1936 & 73.35 & 60.02 & 34.71 & 26.59 & 12.69 & 8.10 & 2.92 \\
\hline 1937 & 76.39 & 65.94 & 42.10 & 33.90 & 17.36 & 12.99 & 6.63 \\
\hline 1938 & 78.38 & 68.60 & 44.92 & 35.94 & 17.29 & 12.64 & 6.11 \\
\hline 1939 & 74.70 & 64.41 & 39.20 & 30.34 & 13.71 & 9.76 & 4.44 \\
\hline 1940 & 82.39 & 71.29 & 46.36 & 37.04 & 18.34 & 13.58 & 6.76 \\
\hline 1941 & 81.72 & 70.83 & 48.40 & 40.19 & 21.60 & 16.70 & 9.19 \\
\hline 1942 & 81.03 & 72.17 & 50.25 & 41.51 & 21.19 & 16.01 & 8.34 \\
\hline 1943 & 80.46 & 71.31 & 47.14 & 38.50 & 19.64 & 14.77 & 7.63 \\
\hline 1944 & 79.96 & 71.05 & 47.92 & 39.15 & 19.74 & 14.74 & 7.48 \\
\hline 1945 & 79.41 & 71.06 & 46.95 & 39.29 & 18.69 & 14.17 & 7.45 \\
\hline 1946 & 81.16 & 73.66 & 50.38 & 42.81 & 18.00 & 13.26 & 4.75 \\
\hline 1947 & 91.48 & 83.83 & 67.56 & 59.12 & 41.43 & 36.15 & 26.66 \\
\hline 1948 & 84.92 & 73.91 & 43.95 & 35.96 & 20.31 & 15.97 & 9.30 \\
\hline 1949 & 85.82 & 75.46 & 44.85 & 35.02 & 18.69 & 14.01 & 6.83 \\
\hline 1950 & 83.89 & 72.64 & 43.28 & 34.44 & 18.68 & 14.21 & 7.22 \\
\hline 1951 & 85.71 & 75.02 & 43.98 & 34.61 & 18.08 & 13.48 & 6.26 \\
\hline 1952 & 85.65 & 68.89 & 44.26 & 34.64 & 17.04 & 12.21 & 5.00 \\
\hline 1953 & 85.52 & 67.10 & 42.53 & 32.76 & 16.28 & 11.45 & 4.35 \\
\hline 1954 & 86.53 & 69.51 & 44.91 & 34.58 & 16.28 & 11.81 & 5.21 \\
\hline 1955 & 87.92 & 71.23 & 47.46 & 36.86 & 17.23 & 12.24 & 5.09 \\
\hline 1956 & 87.40 & 77.56 & 48.41 & 38.71 & 20.04 & 15.58 & 8.74 \\
\hline 1957 & 87.37 & 71.64 & 48.14 & 38.15 & 20.99 & 15.85 & 7.89 \\
\hline 1958 & 86.63 & 69.11 & 45.09 & 32.68 & 16.56 & 11.83 & 5.13 \\
\hline 1959 & 85.43 & 72.32 & 49.54 & 33.16 & 23.30 & 16.96 & 3.98 \\
\hline 1960 & 82.90 & 68.93 & 46.54 & 37.00 & 21.49 & 17.76 & 9.69 \\
\hline 1961 & 84.08 & 68.65 & 44.73 & 35.37 & 18.74 & 12.92 & 6.84 \\
\hline 1962 & 83.61 & 68.26 & 43.49 & 34.77 & 18.48 & 14.09 & 4.74 \\
\hline 1963 & 80.54 & 67.43 & 46.44 & 39.24 & 25.20 & 24.40 & 4.73 \\
\hline 1964 & 80.64 & 67.23 & 43.22 & 35.26 & 20.65 & 15.50 & 7.36 \\
\hline
\end{tabular}


TABLE A2 (Cont.)

\begin{tabular}{|r|r|r|r|r|r|r|r|}
\hline 1965 & 74.37 & 60.45 & 36.72 & 29.10 & 16.02 & 12.44 & 6.83 \\
\hline 1966 & 76.63 & 64.29 & 41.44 & 33.02 & 18.86 & 14.24 & 5.54 \\
\hline 1967 & 73.72 & 61.34 & 39.84 & 31.63 & 17.70 & 14.89 & 3.08 \\
\hline 1968 & 75.79 & 62.65 & 38.28 & 29.98 & 16.32 & 11.59 & 3.43 \\
\hline 1969 & 77.04 & 64.35 & 40.00 & 31.42 & 13.78 & 9.47 & 3.14 \\
\hline 1970 & 72.76 & 60.49 & 36.79 & 28.72 & 14.57 & 9.26 & 2.91 \\
\hline 1971 & 75.29 & 63.09 & 40.60 & 32.28 & 17.35 & 12.97 & 4.81 \\
\hline 1972 & 74.24 & 62.51 & 38.48 & 30.10 & 22.56 & 10.84 & 5.27 \\
\hline 1973 & 74.94 & 62.93 & 36.35 & 27.55 & 12.80 & 8.65 & 3.61 \\
\hline 1974 & 78.93 & 73.50 & 54.99 & 46.99 & 38.26 & 33.48 & 28.73 \\
\hline 1975 & 68.18 & 61.05 & 35.05 & 24.79 & 15.40 & 13.90 & 2.28 \\
\hline 1976 & 64.02 & 54.88 & 27.43 & 22.57 & 9.53 & 5.40 & 1.44 \\
\hline 1977 & 66.84 & 56.85 & 32.54 & 25.07 & 13.44 & 10.06 & 6.13 \\
\hline 1978 & 65.79 & 57.14 & 27.29 & 19.92 & 9.19 & 5.68 & 2.13 \\
\hline 1979 & 68.49 & 55.25 & 23.62 & 16.55 & 7.04 & 5.10 & 2.66 \\
\hline 1980 & 68.49 & 53.67 & 27.13 & 20.06 & 9.56 & 6.41 & 2.21 \\
\hline 1981 & 64.70 & 49.95 & 25.78 & 18.59 & 7.92 & 5.74 & 1.93 \\
\hline 1982 & 63.64 & 49.94 & 26.24 & 19.27 & 8.36 & 5.75 & 2.33 \\
\hline
\end{tabular}

Source: See text. 